\title{
LOS EFECTOS DE LA STC 31/2010 DEL ESTATUTO DE AUTONOMÍA DE CATALUÑA: LAS IMPLICACIONES PARA SU NORMATIVA DE DESARROLLO Y LOS ESTATUTOS DE OTRAS COMUNIDADES AUTÓNOMAS
}

\author{
JUAN CARLOS GAVARA DE CARA \\ Catedrático de Derecho Constitucional \\ Univ. Autónoma de Barcelona
}

\section{SUMARIO}

I. Las repercusiones singulares de carácter procesal del control de constitucionalidad de los Estatutos de Autonomía

II. La escasa incidencia del efecto de cosa juzgada en la STC 31/2010

III. Los efectos generales o frente a todos y sus consecuencias en la STC 31/2010

IV. El efecto de la «vinculación a los poderes públicos» y la articulación de prescripciones derivadas de las sentencias del Tribunal Constitucional

V. La ejecución de las sentencias declarativas de inconstitucionalidad como mecanismo de garantía frente a su incumplimiento

VI. El efecto de vinculación de los poderes públicos y el incumplimiento de las sentencias del Tribunal Constitucional

VII. El efecto de vinculación de los poderes públicos a las sentencias interpretativas del Tribunal Constitucional

VIII. La aplicación de los efectos vinculantes de los poderes públicos a la STC 31/2010 
IX. La incidencia concreta de la STC 31/2010 en la normativa legal autonómica de desarrollo estatutario

X. La extensión de la aplicación de los efectos de la STC 31/2010 a los preceptos idénticos o similares en los otros Estatutos de Autonomía

XI. Conclusión: Los efectos de la STC 31/2010 como una vinculación e incidencia fundamentalmente interpretativa

\section{LAS REPERCUSIONES SINGULARES DE CARÁCTER PROCESAL DEL CONTROL DE CONSTITUCIONALIDAD DE LOS ESTATUTOS DE AUTONOMÍA}

De conformidad con el art. 35.1 LOTC, los efectos de las sentencias del Tribunal Constitucional no solo afectan a los propios de la cosa juzgada, sino también produce los denominados efectos generales de sus sentencias o fuerza de ley y los efectos de vinculación a su contenido de todos los poderes públicos. Esta vinculación de los poderes públicos puede ser de carácter negativo, es decir, de evitar el perjuicio al contenido de la sentencia, pero también de carácter positivo en el sentido de obligación de realizar aquellas actuaciones necesarias para dar un cumplimiento efectivo a la sentencia. Estas actuaciones, que constituyen deberes susceptibles de ser concretados, pueden implicar singularmente para el poder legislativo la adopción de nuevas leyes, sobre todo cuando están afectadas por la declaración directa de inconstitucionalidad de preceptos de un Estatuto de Autonomía, con la finalidad de adecuar su contenido a la sentencia correspondiente. Estas consideraciones permiten destacar que la potestad de declarar la inconstitucionalidad como forma de nulidad de normas con fuerza de ley incide en el sistema de fuentes ya que sus efectos tienen como consecuencia precisamente la abrogación de normas con dicha fuerza ${ }^{1}$, pero también consecuencias en otras normas no directamente impugnadas en los procesos de referencia como pueden ser normas legales adoptadas en desarrollo de los preceptos del Estatuto de Autonomía, así como preceptos similares o idénticos de otros Estatutos de Autonomía que se pueden ver condicionados interpretativamente por el pronunciamiento del Tribunal Constitucional.

El principal problema de la STC 31/2010 deriva de que por primera vez como consecuencia de un control de constitucionalidad se han declarado inconstitucionales determinados preceptos de un Estatuto de Autonomía, es decir, un acto normativo que es norma de cabecera de un ordenamiento jurídico (norma normarum), un acto normativo que determina el sistema de producción normativa de la Comunidad Autónoma desde un punto de vista formal y material, de forma que sus reglas se utilizaron para adoptar normativa de desarrollo generalmente a través leyes autonómicas.

1 Pibernat Domenech, X., «La sentencia constitucional como fuente del Derecho», RDP, 1987, n 24, pág. 59 
La singularidad del supuesto, es decir, la declaración de inconstitucionalidad de un Estatuto de Autonomía del que dependen otros actos normativos autonómicos de carácter legal, implica determinar con posterioridad a la declaración de inconstitucionalidad de preceptos del Estatuto de Autonomía que han sido el fundamento normativo para la adopción de leyes de desarrollo, si por conexión o consecuencia se extiende el pronunciamiento a dichos preceptos, o si por el contrario requieren un pronunciamiento expreso y necesario para su declaración de inconstitucionalidad. En el primer supuesto entre preceptos de leyes de desarrollo del Estatuto de Autonomía que sean idénticos o una consecuencia de los preceptos del Estatuto declarados inconstitucionales se podría plantear un supuesto de inconstitucionalidad derivada, ya que, aunque no formen parte de la misma ley, si que forman parte del mismo mandato y su existencia se encuentra condicionada por la norma principal estatutaria. En este sentido, en el caso de que se adopte una inconstitucionalidad derivada desde un punto de vista sustancial se debe extraer sus consecuencias, sobre todo los efectos en caso de aplicación de las normas cuestionadas, mientras no se declare su inconstitucionalidad expresa en un procedimiento posterior o su derogación por parte del parlamento autonómico.

Las dificultades no finalizan en el examen de las consecuencias dentro del propio ordenamiento autonómico para la normativa de desarrollo estatutario, sino que procede estudiar y analizar si los efectos del pronunciamiento se pueden extender y en qué sentido a preceptos idénticos a los declarados inconstitucionales en otros Estatutos de Autonomía. En este supuesto, la inconstitucionalidad no puede ser de carácter derivado, sino que se debe examinar el alcance de los efectos vinculatorios sobre todo de carácter interpretativo en los supuestos concretos que se pueden ver afectados.

La clave para la comprensión de estos triples efectos (cosa juzgada, fuerza de ley y vinculación a los poderes públicos) es determinar el alcance y el sentido de los efectos ergaomnes, es decir, los efectos generales frente a todos y, consecuentemente, vinculantes para todos los poderes públicos, que desde un punto de vista constitucional comprende ambas consecuencias o derivaciones ${ }^{2}$. El principio del Estado de Derecho a través de la exigencia de seguridad jurídica excluiría tanto la aplicación de la ley inconstitucional como el mantenimiento y la creación de leyes inconstitucionales con el mismo mandato normativo, ya que se trataría de un claro incumplimiento de las sentencias del Tribunal Constitucional.

El art. 164 CE establece que las sentencias del Tribunal Constitucional «tienen el valor de cosa juzgada desde el día siguiente de su publicación y no cabe recurso alguno contra ellas», añadiendo que «las que declaren la inconstitucionalidad de una ley o de una norma con fuerza de ley y todas las que no se limiten a la estimación subjetiva de un derecho, tienen plenos efectos frente a todos». Estos efectos generales, frente a todos, comprensivo del alcance de su vinculación son predicables de aquellas que no se limiten a la estimación subjetiva de un derecho, por lo que cabe deducir que es predicable de las

2 Las tres categorías conceptuales cosa juzgada (Rechtskraft), vinculación de los poderes públicos (Bindungswirkung) y fuerza de ley (Gesetzeskraft) son de una clara influencia alemana conectada a los efectos de la sentencias del Tribunal Constitucional alemán. Vid. Bocanegra Sierra, R., El valor de las sentencias del Tribunal Constitucional, IEAL, Madrid, 1982, pág. 29. 
sentencias de control de constitucionalidad con independencia de que declare o no la inconstitucionalidad de una ley.

En consecuencia, los efectos de una sentencia del Tribunal Constitucional de declaración de inconstitucionalidad tienen carácter general, es decir, no son pronunciamientos vinculantes exclusivamente a las partes del proceso concreto sin trascendencia exterior o de limitación exclusiva al fallo de la sentencia, es decir, a lo decidido sin poder ir más allá del pronunciamiento declarativo, de conformidad con la doctrina clásica propia del proceso civil. Las decisiones que adopta el Tribunal Constitucional afectando a la distribución de competencias entre los distintos poderes, es decir, un elemento central de la estructura constitucional, tienen una trascendencia e incidencia en el resto de los poderes públicos con independencia de que hayan sido parte en el proceso, y con mayor razón por producir unos efectos generales vinculados a una sentencia declaratoria de la inconstitucionalidad de preceptos de un Estatuto de Autonomía.

La elaboración de la LOTC adoptó una perspectiva típicamente jurisdiccional regulando la mayoría de los efectos de sus sentencias, para garantizar de que se traten de verdaderos pronunciamientos judiciales, con intervención y defensa de las partes, fundamentación jurídica completa y eficacia de sus pronunciamientos, de forma que no se puedan considerar manifestación de una voluntad política. La exigencia de que las sentencias del Tribunal Constitucional sean vinculantes es una necesidad para el cumplimiento efectivo e independiente de las funciones de una institución dirigida a interpretar y garantizar la adecuación del desarrollo y de la aplicación del ordenamiento jurídico a la Constitución, sobre la base de ostentar el monopolio de rechazo de las leyes inconstitucionales.

En cualquier caso, los efectos vinculantes de las sentencias del Tribunal Constitucional y particularmente los que afectan a un Estatuto de Autonomía no se pueden realizar exclusivamente en abstracto, sino que debe ser el objeto de un contraste y análisis particular desde un punto de vista sustancial en cada supuesto concreto para valorar correctamente las consecuencias de la declaración de inconstitucionalidad y nulidad o la declaración de una interpretación conforme a la Constitución de los preceptos de un Estatuto de Autonomía.

\section{LA ESCASA INCIDENCIA DEL EFECTO DE COSA JUZGADA EN LA STC 31/2010}

La idea de cosa juzgada del proceso ordinario no puede ser objeto de una transposición directa al proceso constitucional, ya que el Tribunal Constitucional puede enjuiciar de nuevo sus decisiones. En caso contrario, se impediría la adaptación y apertura de la Constitución a posibles desarrollos futuros e implicaría que una primera decisión sobre un tema fuera la única posible interpretación correcta sin posibilidad de contemplar errores o cambios en los criterios por parte del Tribunal Constitucional. Del mismo modo tampoco sería admisible la posibilidad de repetir, mantener y replantear indefinidamente la misma cuestión y el mismo conflicto sin infringir la paz y seguridad jurídicas que configuran una parte esencial del principio del Estado de Derecho. Entre un extremo y otro se sitúan los posibles efectos que se pueden derivar de la cosa juzgada en materia de control de constitucionalidad de las leyes. 
El efecto de cosa juzgada tiene una función negativa, ne bis in idem, que impide la apertura de nuevos procesos con el mismo objeto y las mismas partes, vinculando a cualquier juez, en este caso al Tribunal Constitucional, que pueda con posterioridad reabrir la causa (en el caso de que sea posible en materia de control de constitucionalidad dado la brevedad de los plazos para el planteamiento de un recurso) ${ }^{3}$, y una función positiva, que impide que en un nuevo proceso se decida de modo contario a cómo fue fallado con anterioridad, es decir, genera un precedente vinculatorio para los poderes públicos que deben atenerse al fallo, pero que en nuestro supuesto es exterior a la propia actividad del Tribunal Constitucional que no se encuentra obligado por sus propios precedentes (principio de reversibilidad de los precedentes) $)^{4}$.

Con la vinculación a la cosa juzgada se pretende evitar la litigación recurrente de la misma controversia (en este sentido vincula a las partes, extinguiendo su capacidad de reacción) y, al mismo tiempo, evitar que se produzcan sentencias contradictorias en el mismo asunto (vinculando a los jueces), pero en el caso del Tribunal Constitucional sin consecuencias concretas. La cosa juzgada formal hace referencia a la firmeza de la sentencia, que se predica como inimpugnable sin admitir excepciones (en la práctica impide que las partes acudan a una instancia superior y soliciten una revisión de la resolución, es decir, la decisión judicial es irrecurrible). La cosa juzgada material es la que impide que el mismo asunto vuelva a ser objeto de litigio ante los tribunales, cerrando el paso a un «bis in idem», es decir, opera en sucesivos procesos impidiendo la reiteración de las cuestiones resueltas. En el proceso constitucional el efecto de cosa juzgada se proyecta exclusivamente en relación al fallo de la sentencia constitucional y no sobre los fundamentos jurídicos de la misma ${ }^{5}$. Dentro de este contexto las repercusiones del efecto de cosa juzgada a partir de la STC 31/2010 tienen una escasa incidencia en otras normas o procesos, ya que las partes no pueden volver a presentar otro recurso de inconstitucionalidad, ni se puede recurrir la sentencia del Tribunal Constitucional, ni se pueden volver a reiterar las cuestiones efectivamente resueltas.

En definitiva, no cabe duda que todas las sentencias constitucionales en materia de control de constitucionalidad poseen eficacia de cosa juzgada formal, pues como indican tanto la Constitución (art. 164.1 CE) como la LOTC (el art. 93.1 LOTC solo admite que se puedan solicitar aclaraciones) contra ellas no cabe recurso alguno. Sin embargo, la eficacia de cosa juzgada material es discutida en relación con las sentencias que deciden procesos de declaración de inconstitucionalidad, constituyendo esta una de las especialidades de la jurisdicción constitucional en comparación con la jurisdicción ordinaria. La primera razón es que el reconocimiento del efecto de cosa juzgada material tendría la consecuencia de impedir ulteriores pronunciamientos sobre la constitucio-

3 Pibernat Domenech, X., «La sentencia constitucional como fuente del Derecho», op. cit., pág. 62 y Gómez Montoro, A. J., «Comentario artículo 38 LOTC», en AAVV, Comentarios a la Ley Orgánica del Tribunal Constitucional, TC-BOE, Madrid, 2001, pág.560-561.

4 La no vinculación del Tribunal Constitucional a sus propios precedentes constituye la regla general en el derecho comparado, vid. Pibernat Domenech, X., «La sentencia constitucional como fuente del Derecho», op. cit., pág. 63 y Garronea Morales, A., «Artículo 164: Condiciones y efectos de las sentencias del Tribunal Constitucional», AAVV, Comentarios a la Constitución Española de 1978, Tomo XII, Cortes Generales-EDERSA, Madrid, 1999, pág. 348 y ss.

5 Gómez Montoro, A. J., «Comentario artículo 38 LOTC», op. cit., pág. 565. 
nalidad de la misma ley. En la práctica este efecto impediría al Tribunal Constitucional volver sobre su jurisprudencia anterior al cerrar una vía para la revisión de la jurisprudencia y convertiría a la ley ya examinada en inimpugnable en el futuro, al menos por los motivos de inconstitucionalidad que el Tribunal entró a conocer en la sentencia desestimatoria (la existencia de dos vías, el recurso y la cuestión de inconstitucionalidad, teniendo en cuenta que tiene la segunda vía una vocación de apertura tras el ejercicio de la segunda —art. 29.2 y 38.2 LOTC—, implicaría una singularidad notable del instituto en la jurisdicción constitucional). No obstante, existe una segunda razón, ya que el efecto de cosa juzgada material no añadiría ninguna consecuencia en los procesos de declaración de inconstitucionalidad y quedaría subsumido en los «efectos generales»o «plenos efectos frente a todos» de la declaración de inconstitucionalidad y nulidad, ya que no es posible una nueva impugnación dirigida contra la norma ya declarada inconstitucional y expulsada del ordenamiento, siendo la aplicación del instituto innecesaria. En relación al caso particular de la STC 31/2010 sobre el Estatuto de Autonomía de Cataluña nada impide que se pueda plantear una cuestión de inconstitucionalidad sobre algún precepto estatutario en la medida en que se puedan considerar aplicables en un caso concreto, que por la propia naturaleza del Estatuto de Autonomía no es un hecho frecuente, ya que la aplicación de los procesos jurisdiccionales ordinarios es más habitual sobre la normativa de su desarrollo.

En cualquier caso, el Tribunal Constitucional, en la práctica, ha inadmitido a trámite cuestiones de inconstitucionalidad o ha considerado extinguido su objeto por razón de que la cuestión, habiendo sido decidida y juzgada en un procedimiento anterior, ya «estaba resuelta» (excepción de cosa juzgada material). Pero también en otras ocasiones, habiendo recaído ya una decisión (desestimatoria) sobre la misma ley, el Tribunal no ha tenido inconveniente en proceder a un «reexamen» de la cuestión, normalmente para reiterar, confirmar, o clarificar, su argumentación anterior. En definitiva, la apreciación del efecto de cosa juzgada material depende, en cada caso, del propio Tribunal Constitucional, pero, sin embargo, no va a plantear excesivas consecuencias en los preceptos del Estatuto de Autonomía que no se dirigen a ordenar, ni a regular relaciones jurídicas aplicables de forma directa en los procesos jurisdiccionales ordinarios.

No obstante, se puede plantear qué sucede cuando el legislador vuelve a aprobar una ley con un precepto con contenido idéntico al declarado inconstitucional a pesar del mandato de no reactivar la inconstitucionalidad declarada mediante la reiteración de la regla inconstitucionalidad ${ }^{6}$. En nuestro caso, se debe partir de la idea de que es difícil que se pueda volver a aprobar preceptos del Estatuto de Autonomía con el mismo contenido declarado inconstitucional, ya que la necesaria concurrencia de voluntades políticas dificultaría la adopción de este tipo de decisión. En todo caso, en este supuesto se debe determinar si se produce un efecto pro futuro sobre una norma aprobada con posterioridad a la declarada inconstitucional, debiéndose concluir que en principio será necesaria una nueva declaración de inconstitucionalidad, ya que una identidad absoluta no se produciría, de forma que se adoptaría una nueva norma estatutaria (aunque fuera similar o idéntica a la anterior) y cabe una revisión y modificación de la jurisprudencia anterior del Tribunal Constitucional, lo que exige desde ambas perspectivas un nuevo pronuncia-

6 STC 146/1994 FJ 2 
miento $^{7}$. En cualquier caso, la repetición de precepto estatutario declarado previamente inconstitucional debe ser examinado no solo desde la perspectiva del efecto de cosa juzgada, sino también desde la perspectiva del efecto de vinculación de los poderes públicos a las sentencias del Tribunal Constitucional, tal como se analizará en apartados posteriores.

Por último, se debe analizar si se puede plantear como casos de aplicación del efecto de cosa juzgada material la pendencia ante el Tribunal Constitucional de otros procesos sobre la misma norma que no hubieran sido acumulados a la previa sentencia ${ }^{8}$. En estos casos el Tribunal plantea la desaparición sobrevenida del objeto sin que sea necesario un nuevo pronunciamiento, ya que con efectos ergaomnes la norma legal o en este caso estatutaria previamente declarada inconstitucional y nula ya no existe, de forma que en sentido estricto no estamos ante un efecto de cosa juzgada material ${ }^{9}$.

\section{LOS EFECTOS GENERALES O FRENTE A TODOS Y SUS CONSECUENCIAS EN LA STC 31/2010}

El art. 164 CE atribuye «plenos efectos frente a todos» a las sentencias constitucionales estimatorias de la inconstitucionalidad y a todas «las que no se limiten a la estimación subjetiva de un derecho». El art. 38.1 LOTC establece que «las sentencias recaídas en procedimientos de inconstitucionalidad... producirán efectos generales desde la fecha de su publicación en el Boletín Oficial del Estado», por lo que no excluye que puedan tener efectos tanto las sentencias estimatorias como las desestimatorias en los procesos declarativos de inconstitucionalidad, pero lo cierto es que una sentencia desestimatoria no tiene una especial incidencia ${ }^{10}$, debido a que no se produce ninguna consecuencia de innovación en el ordenamiento jurídico.

Los efectos generales de las sentencias del Tribunal Constitucional, supone un reconocimiento similar a los efectos de fuerza de ley planteados en el sistema constitucional alemán ${ }^{11}$, que permite deducir que los efectos se extiendan no solo a los poderes públicos, sino a todas las personas físicas y jurídicas, ya que obligarían directamente en la esfera de sus derechos y obligaciones. Los efectos de una sentencia constitucional no que-

7 Díaz Revorio, F. J., Las sentencias interpretativas del Tribunal Constitucional, Lex Nova, Valladolid, 2001, pág. 126. Vid. STC 82/1982 FJ 1 que considera necesario dos pronunciamientos distintos y STC 23/1988 FJ 2 que exige un necesario planteamiento de cuestión de inconstitucionalidad ante la inaplicación de un precepto legal similar a dos previamente declarados inconstitucionales. En nuestra doctrina la reproducción de otra ley de un precepto inconstitucional no se considera un supuesto del efecto de cosa juzgada, vid. GómEz MONTORO, A. J., «Comentario artículo 38 LOTC», op. cit., pág. 563.

8 Este hecho ha pasado en nuestro caso de referencia con todos los procesos resueltos posteriormente sobre el Estatuto de Cataluña, resueltos por las STC 46/2010, STC 47/2010, STC 48/2010, STC 49/2010, y de los recursos planteados por la Comunidad Autónoma de La Rioja y el Defensor del Pueblo (STC 137/2010 y STC 138/2010).

9 Garrorena Morales, A., op. cit., pág. 343

10 Vid. Gómez Montoro, A. J., «Comentario artículo 38 LOTC», op. cit., pág. 568

11 Aunque parte de la doctrina considera que se tratan de efectos diferentes, vid. Gómez Montoro, A. J., «Comentario artículo 38 LOTC», op. cit., pág. 569. 
dan limitados a las partes que intervinieron en el proceso, ya que estos efectos se proyectan hacia el futuro y obligan a todos, poderes públicos y particulares.

Los efectos generales implican que las decisiones del Tribunal Constitucional tienen efectos semejantes a la ley, efectos ergaomnes, de forma que la conexión entre inconstitucionalidad y nulidad permite deducir una función reparadora de la juridicidad y unos efectos de expulsión del ordenamiento que son irreversibles. En general, el valor y los efectos de las sentencias del Tribunal Constitucional deben ser idénticos a los de la norma impugnada y objeto del pronunciamiento, es decir, similar a la ley o al Estatuto de Autonomía en el presente caso. Este es un punto relativamente importante por el hecho de que el Estatuto de Autonomía tiene una incidencia directa en otros actos normativos y normas de carácter legal del propio ordenamiento autonómico. En este sentido, se debe destacar que por primera vez se ha procedido a declarar inconstitucionales preceptos de un Estatuto que actúa como norma de cabecera de un ordenamiento jurídico, de forma que se debe analizar la incidencia en otros actos normativos con rango legal dependientes de los preceptos estatutarios sometidos s una declaración de inconstitucionalidad o a una interpretación conforme con el texto constitucional. En consecuencia, en el presente caso el valor y los efectos de las sentencias del Tribunal Constitucional en relación con el Estatuto de Autonomía deben asimilarse al propio valor normativo del Estatuto con las consecuencias que se puedan deducir e implicar en el propio ordenamiento autonómico catalán.

Desde otra perspectiva, con la expresión «plenos efectos frente a todos» se quiere aludir a algo diferente de la obligación que pesa sobre los poderes públicos de cumplir con lo que el Tribunal resuelva (art. 87.1 LOTC). Los efectos generales son de carácter normativo, es decir, son los efectos que producen aquellas sentencias constitucionales que innovan el ordenamiento, que producen una alteración del Derecho en vigor, bien porque anulan preceptos, bien porque alteran las condiciones de su aplicación, bien porque tienen el efecto de introducir «nuevas» reglas en sustitución de otras que se anulan o, directamente, dirigidas a ocupar espacios vacíos de regulación. En cualquier caso, los efectos generales de las sentencias del Tribunal Constitucional en si mismos considerados no requieren actuaciones de cumplimiento efectivo por parte de los poderes públicos, ya que sus consecuencias son predicables directamente por la propia sentencia del Tribunal Constitucional. En todo caso para un supuesto particular como la STC 31/2010 requiere aclaraciones sobre su alcance, ya que nunca se había adoptado una declaración de inconstitucionalidad sobre un acto normativo que mantenga relaciones jurídicas de jerarquía con otros actos normativos con rango de ley, dejando al margen algunos supuestos de relaciones entre legislación delegada y decretos legislativos en los que se llegó a reconocer identidad procesal en la jurisprudencia constitucional.

De todos modos, aunque los efectos generales de la STC 31/2010 deben valorar el hecho de que los Estatutos de Autonomía es norma de cabecera en relación a los preceptos estatutarios declarados inconstitucionales y nulos o sometidos a una interpretación conforme a la Constitución, el alcance y el valor de la STC 31/2010, así como las repercusiones en la normativa de desarrollo estatutario o en los preceptos de los Estatutos de otras Comunidades Autónomas se debe determinar en concreto, para lo cual debe ser examinada la fundamentación jurídica de la resolución y no solo el fallo específico. 
En este sentido, las sentencias interpretativas en la medida en que tienen el efecto de modificar la interpretación de un precepto producen una «alteración» del Derecho aplicable y gozan de efectos generales. Este supuesto permite deducir con claridad que los efectos generales son predicables de la fundamentación jurídica de la sentencia y no solo del fallo de la misma ${ }^{12}$, ya que además el carácter interpretativo deducible de la fundamentación de una sentencia estimatorias es aplicable a supuestos como el de las normas paralelas (propio del Derecho alemán para extender los efectos de las sentencias de control de leyes de los Länder a otras leyes idénticas o similares de otros Länder, o en nuestro caso para los preceptos idénticos o similares de los Estatutos de otras Comunidades Autónomas) a partir de la fundamentación y no exclusivamente por el fallo de la resolución.

\section{EL EFECTO DE LA «VINCULACIÓN A LOS PODERES PÚBLICOS» Y LA ARTICULACIÓN DE PRESCRIPCIONES DERIVADAS DE LAS SENTENCIAS DEL TRIBUNAL CONSTITUCIONAL}

El art. $164 \mathrm{CE}$ no se refiere de forma expresa a este efecto de la sentencia constitucional, pero el art. 38.1 LOTC con claridad establece el efecto de vinculación de los poderes públicos a propósito de los efectos de las sentencias recaídas en procedimientos de control de constitucionalidad. Este efecto no tiene carácter procesal, sino material o sustancial, ya que cumple la función de garantizar la obligatoriedad del cumplimiento de las decisiones del Tribunal, con la consecuencia de que los poderes públicos en el ámbito de sus competencias tienen la obligación de adoptar decisiones, resoluciones y los actos necesarios para revocar, derogar o revertir las situaciones, relaciones o normas que sean contrarias a las decisiones del Tribunal Constitucional. Del mismo modo, el efecto de la vinculación también permite derivar una correspondiente prohibición de mantener un comportamiento contrario a la decisión adoptada.

Cuando se indica que las sentencias «vincularán a los poderes públicos» no se está simplemente recordando que los poderes públicos deben acatar y, en su caso, ejecutar lo que el Tribunal resuelva. Si algún sentido tiene la especificación del efecto de «vinculación a los poderes públicos», hay que partir de la idea de que se tratará de algo diferente del efecto de cosa juzgada y de la eficacia ergaomnes. El efecto de cosa juzgada es un efecto que circunscribe su alcance al ámbito de la relación procesal (impide la litigación recurrente de la misma cuestión) y se predica del fallo de las decisiones judiciales. El efecto ergaomnes es el que producen las sentencias constitucionales que tienen el efecto de innovar el ordenamiento, produciendo una alteración en el derecho aplicable o en vigor, por lo tanto solo es deducible de las sentencias que estiman en general la inconstitucionalidad de una norma legal o de carácter interpretativo. El efecto de la vinculación de los poderes públicos obliga a estos a desempeñar su función atendiendo a las pautas y criterios de la doctrina constitucional, es decir, añade una nueva dimensión a la eficacia de las sentencias constitucionales, de carácter prescriptivo, estableciendo obligaciones y prohi-

12 Tal como plantea parte de la doctrina, vid. Gómez Montoro, A. J., «Comentario artículo 38 LOTC», op. cit., pág. 567. 
biciones para los poderes públicos que se desprenden de la jurisprudencia o doctrina del Tribunal Constitucional ${ }^{13}$. Se trata de un efecto que es predicable de cualquier sentencia del Tribunal Constitucional y que comprende un deber positivo y negativo para los sujetos afectados, es decir, los poderes públicos en general y sin exclusiones, pero no a los ciudadanos ${ }^{14}$. La producción de este efecto es coherente con la posición institucional del Tribunal Constitucional como intérprete supremo de la Constitución y órgano de solución de controversias a propósito de la interpretación de la Constitución y encargado de determinar la interpretación del Derecho conforme a la Constitución.

La vinculación de los poderes públicos a las sentencias del Tribunal Constitucional implica que se extiende más allá de las partes del proceso y del caso concreto decidido, vinculando en casos futuros a todos los órganos constitucionales y estatutarios, así como a tribunales y administración ${ }^{15}$. Esta vinculación alcanza no solo el tenor literal del fallo, sino las consideraciones y fundamentación jurídica que sustenta dicho fallo, es decir, las razones relevantes que han motivado la adopción de la decisión concreta (la ratio decidendi o tragende Gründe $)^{16}$. El mismo hecho de que las sentencias del Tribunal Constitucional se deban motivar permite deducir que la vinculación a sus sentencias alcanza no solo al fallo, sino al contenido de la fundamentación ${ }^{17}$. En este sentido, se puede comprender el efecto de vinculación a las sentencias de declaración de inconstitucionalidad sin nulidad, las sentencias interpretativas o las desestimatorias de la inconstitucionalidad.

El propio Tribunal Constitucional no se encuentra vinculado a su propio poder de decisión, ya que se puede separar en un futuro de sus decisiones vinculantes. La finalidad es articular una vinculación que implique que se corrijan los preceptos que puedan incurrir por derivación en la misma inconstitucionalidad, que impida que las decisiones declaradas inconstitucionales se puedan volver a reiterar o mantener y fijar las vías por las que debe discurrir las decisiones y actuaciones de los poderes públicos en el futuro. No se puede pensar que una sentencia es puramente declarativa sin efectos que vayan más allá de la inconstitucionalidad y nulidad de preceptos jurídicos, es decir, una decisión teórica, poco efectiva y sin consecuencias jurídicas concretas, ya que puede ser susceptibles de ser tratadas a partir de efectos de carácter prescriptivo concretables en obligaciones y prohibiciones en las actuaciones de los poderes públicos.

13 Vid. Garronea Morales, A., op. cit., pág. 375

14 Vid. Gómez Montoro, A. J., «Comentario artículo 38 LOTC», op. cit., pág. 570

15 El efecto de la vinculación de los poderes públicos a las sentencias es considerado innecesario por estar integrado en el efecto de cosa juzgada por parte de la doctrina, vid. Bocanegra Sierra, R., op. cit., pág. 82 y ss. y pág. 108 y ss.

16 Vid. Pibernat Domenech, X., «La sentencia constitucional como fuente del Derecho», op. cit., pág. 67. La interpretación más extendida es la de que con esta expresión se alude a la vinculación de los poderes públicos a la doctrina constitucional, tal y como se deriva de los fundamentos de las sentencias constitucionales (tragende Gründe). De forma que los poderes públicos no sólo resultan obligados a cumplir lo que el Tribunal Constitucional resuelva, lo que el fallo de la sentencia disponga. Los poderes públicos habrán de conformar su actuación a las pautas marcadas por la doctrina del Tribunal y, en su calidad de aplicadores del derecho, quedan vinculados por los criterios sobre interpretación y aplicación del derecho conforme a la Constitución que el Tribunal establece con ocasión de la resolución de los casos que llegan a él.

17 Sobre la motivación de las sentencias del Tribunal Constitucional, vid., Garronea Morales, A., op. cit., pág. 307 y ss. 
En este sentido, la vinculación de los poderes públicos puede ser de carácter positivo, es decir, una vinculación que implica para el legislador la obligación de no volver a aprobar otra ley con el mismo contenido declarado inconstitucional, la exigencia de cambios en la ley impugnada estableciendo incluso un plazo para su realización, o si se ha fijado una determinada interpretación del precepto impugnado, todos los poderes públicos encargados de la aplicación de preceptos se encuentran vinculados a dicha interpretación en sus respectivas actuaciones.

El problema para nuestro caso concreto es que si se declara una norma inconstitucional y esta tiene rango estatutario, todas las normas adoptadas bajo su cobertura participan de dicha decisión con independencia de que adopten forma legal o reglamentaria, ya que la decisión de inconstitucionalidad afecta al mismo mandato con independencia de la forma normativa que adopte, produciendo efectos vinculantes a cualquier poder público.

De todas formas, la vinculación del legislador a la doctrina del Tribunal no puede implicar la supresión de sus posibilidades como intérprete de la Constitución, ni puede suponer la progresiva reducción de su ámbito de libertad de configuración. Aunque la cuestión es debatida, nada impide, en principio, que el legislador apruebe leyes que entren en conflicto con la doctrina constitucional, que incluso se pueden considerar dirigidas precisamente a provocar la revisión por parte del Tribunal de su doctrina. Ahora bien esta posibilidad es admisible siempre que no se trate de un ejercicio arbitrario de su potestad, ya que esta no se puede ejercer al margen de los criterios de constitucionalidad establecidos por el Tribunal en su doctrina jurisprudencial, es decir, con un mínimo de motivación sobre la diferencia con las anteriores decisiones del legislador declaradas inconstitucionales. El Tribunal Constitucional tiene, en todo caso, la última palabra en materia de interpretación constitucional, pero deben dejarse abiertas las puertas para supuestos de modificación, revisión o, directamente, revocación de la doctrina jurisprudencial previamente establecida ${ }^{18}$.

Esta visión no puede considerarse una regla general, la consecuencia de la vinculación del legislador a las sentencias del Tribunal Constitucional es una derivación de los plenos efectos frente a todos a excepción de las sentencias que resuelvan recursos de amparo, de forma que queda vinculado por las declaraciones de inconstitucionalidad de la ley, por las sentencias de conformidad que interpreten la norma constitucional y por las sentencias interpretativas. Las sentencias del Tribunal Constitucional deben ser consideradas fuente del Derecho, no solo porque declaran la nulidad de normas legales, sino porque la interpretación de las normas realizada en las sentencias se vincula de forma inseparable con la norma interpretada, con la consiguiente consecuencia de que la sentencia del Tribunal Constitucional puede ser considerada como creadora de Derecho ${ }^{19}$. De este modo, la jurisprudencia del Tribunal Constitucional supera el carácter limitado otorgado a la jurisprudencia por el art. 1.6 CC, es decir, no se trata de un mero complemento del ordenamiento jurídico, ya que el efecto vinculatorio a las sentencias del Tribunal Constitucional es de mayor alcance al planteado por el Código $\mathrm{Civil}^{20}$.

18 Vid. un caso de revocación de doctrina constitucional, indirectamente provocado por el legislador, en las STC 179/1994 FJ 10 y STC 107/1996 FJ 10-11

19 Pibernat Domenech, X., «La sentencia constitucional como fuente del Derecho», op. cit., pág. 85

20 Vid. Gómez Montoro, A. J., «Comentario artículo 38 LOTC», op. cit., pág. 569. 
En general, la interpretación de la ley realizada por la sentencia del Tribunal Constitucional, no es superior a la ley, ni se sitúa en un escalón intermedio entre la Constitución y la ley, sino que la interpretación de la norma realizada en la sentencia del Tribunal Constitucional se identifica con la norma interpretada, ocupando su mismo rango jerárquico con sus mismos efectos en el ámbito de la producción normativa. En este caso estamos ante un Estatuto de Autonomía que genera efecto de cobertura jurídica sobre las leyes de desarrollo y despliegue directo a través de otros actos normativos con rango de ley. De esta forma, los condicionamientos de una declaración de inconstitucionalidad de preceptos estatutarios son específicos y singulares, debido a que se trata de una norma de cabecera susceptible de generar efectos en otros preceptos de otros actos normativos dependientes jerárquicamente, siempre que se plantee una relación de identidad directa que implica que se incurra en el mismo mandato declarado inconstitucional.

La vinculación de los jueces a la doctrina del Tribunal es mucho más potente y directa, como se desprende de lo dispuesto en los arts. 5 y 7.2 LOPJ. Los jueces no pueden desafiar ni desconocer la doctrina del Tribunal, pero pueden utilizar vías a su alcance para incidir y provocar al Tribunal Constitucional a pronunciarse sobre su doctrina anterior y, en su caso, a modificarla ${ }^{21}$. Para el Poder judicial es un deber atenerse a la doctrina constitucional $^{22}$, que tiene un verdadero valor de precedente ${ }^{23}$, con unas consecuencias lesivas del derecho a la tutela judicial efectiva, en el momento en que decide apartarse de la doctrina constitucional. A pesar de las críticas a la innecesariedad de regular los efectos previstos en el art. 5.1 LOPJ, lo cierto es que ha clarificado la vinculación de jueces y tribunales a las resoluciones del Tribunal Constitucional en todo tipo de procesos ${ }^{24}$. En estos supuestos los criterios interpretativos derivables de los preceptos declarados inconstitucionales y nulos del Estatuto de Autonomía, así como las interpretaciones conforme a la Constitución de los preceptos estatutarios concretada en la STC 31/2010, son aplicables como precedentes por el poder judicial en todos los casos y procesos en los que sean susceptibles de ser aplicados.

La vinculación de la administración a la doctrina del Tribunal es una vinculación normalmente indirecta y mediada por la ley y la jurisprudencia de los tribunales ordinarios. El principio de legalidad y de imperio de la ley implica que la sujeción de los órganos administrativos, como la de los ciudadanos, sea reconducible a la sujeción de los jueces y tribunales ${ }^{25}$. En estas situaciones se ha planteado que en su actuación los órganos de la administración deberán atenerse a la doctrina del Tribunal, pero no podrán dejar de aplicar una ley o separarse de lo dispuesto en un reglamento por razón de que esté en

21 Por ejemplo, un juez, disconforme con la conclusión de «no inconstitucionalidad» de una ley, puede plantear una nueva cuestión de inconstitucionalidad, ofreciéndole al Tribunal los motivos que a su juicio conducen a sostener su inconstitucionalidad, vid. STC 222/1992 FJ 2.

22 STC 319/1993 FJ 2

23 STC 65/1990 FJ 2. Vid. JiméNEZ CAMPO, J., «Qué hacer con la ley inconstitucional», AAVV, La sentencia sobre la constitucionalidad de la ley, Actas de las II Jornadas de la Asociación de Letrados del Tribunal Constitucional, TC-CEPC, Madrid, 1997, pág. 29

24 Vid. Garronea Morales, A., «Opacidad y desestimación de la inconstitucionalidad en el fallo de las sentencias interpretativas», Anuario de Derecho Constitucional y Parlamentario, 2002-03, no 12-13, pág. 151 y ss. y 161 y ss.

25 Pibernat Domenech, X., «La sentencia constitucional como fuente del Derecho», op. cit., pág. 70 
conflicto con la doctrina del Tribunal Constitucional, lo que tiene repercusión sobre todo en relación con las sentencias interpretativas. En caso de conflicto prevalece siempre la interpretación que sobre el Derecho aplicable imponen los jueces, de forma que una actuación de la administración contraria a la pauta establecida por la doctrina constitucional puede ser por este motivo impugnada.

En cualquier caso, este criterio no puede ser considerado una regla general, de modo que debe ser matizado, ya que puede implicar tensiones con el principio de seguridad jurídica. El criterio de la Ley 30/1992 (Ley de Régimen Jurídico de las Administraciones Públicas y del Procedimiento Administrativo Común-RJAPyPAC) es que no pueden admitirse las disposiciones reglamentarias contrarias o vulneradoras de la Constitución y se plantea una exigencia general de ajustar la actividad administrativa al ordenamiento jurídico, de forma que no cabe admitir que conscientemente la administración en su actuación no se adecue a la Constitución y su significado concretado a través de las decisiones del Tribunal Constitucional. En este sentido, el art. 62.2 Ley 30/1992 establece la nulidad de pleno derecho de las disposiciones reglamentarias vulneradoras de la Constitución, lo cual se debe extender a los criterios fijados por el Tribunal Constitucional en sentencias estimatorias de inconstitucionalidad o interpretativas. Difícilmente se puede entender que la norma atributiva legal o estatutaria de competencia para adoptar la disposición reglamentaria sea inconstitucional y los órganos administrativos continúen aplicando dicha norma a consecuencia del principio de jerarquía administrativa y no del principio de jerarquía normativa, ni cabe esperar a un control judicial posterior para hacer efectiva la decisión de inconstitucionalidad del Tribunal Constitucional. La declaración de inconstitucional debe implicar que dicha norma reglamentaria no debe producir ningún efecto directo o indirecto, es decir, ningún efecto pro futuro, de forma que ningún poder público en virtud de su sometimiento a la Constitución y a los efectos generales de las sentencias del Tribunal Constitucional, podrá aplicar la norma inconstitucional o de preceptos en otros actos normativos reiterativos de la misma desde el momento en que ha sido declarado nula ${ }^{26}$. Por otra parte, el reglamento dictado a consecuencia de una ley inconstitucional o que se mantiene vigente tras la declaración de inconstitucionalidad carece de fundamento constitucional y no solo de base legal, de forma que la sentencia declaratoria de inconstitucionalidad tiene efectos retroactivos y dejará de tener cobertura constitucional y legal desde la adopción de la norma declarada inconstitucional. El reglamento disconforme con la Constitución y la ley al carecer de amparo en virtud de una decisión de declaración de ley inconstitucional del Tribunal Constitucional, implicará que sus preceptos sean nulos de pleno derecho con ineficacia jurídica absoluta y no objeto de convalidación bajo ninguna circunstancia ${ }^{27}$.

26 Esta inaplicabilidad por ciudadanos y poderes públicos de la norma declarada inconstitucional ha sido reconocida por el Tribunal Constitucional, que ha indicado la radical y absoluta imposibilidad de aplicación de la norma ya declarada inconstitucional (STC 153/1986 FJ 2, que alcanza al poder judicial (STC 152/1986 FJ 1; STC 19/1987 FJ 1, órganos administrativos (STC 19/1987 FJ 6) o incluso particulares (STC 147/1986 FJ 6). Vid. Pibernat Domenech, X., «Los efectos de la declaración de inconstitucionalidad. Algunas consideraciones a propósito de la STC 60/1986, de 20 de mayo», RJC, 1987, n 4, pág. 980.

27 Pibernat Domenech, X., «Los efectos de la declaración de inconstitucionalidad. Algunas consideraciones a propósito de la STC 60/1986, de 20 de mayo», op. cit., pág. 982. 
La redacción de los efectos conectados a la declaración de inconstitucional es muy estricta, según el tenor de la LOTC (art. 27.2, 39.1 y 40.1 LOTC), ya que limita la declaración de inconstitucionalidad a los preceptos impugnados o a otros preceptos de la misma ley, disposición o acto con fuerza de ley por conexión o consecuencia. A pesar de la ingenuidad de este precepto, lo cierto es que podemos comprobar la existencia de sentencias interpretativas, de reconocimiento de inconstitucionalidades por omisión o efectos de ultraactividad de normas no previstos expresamente en los mencionados preceptos, pero la LOTC establece que la declaración de nulidad solo afecta en principio a los preceptos de la norma inconstitucional, no pudiendo ser extendidos a preceptos de un reglamento ejecutivo de la ley inconstitucional o de otros leyes adoptadas con fundamentación directa en una norma superior declarada inconstitucional a diferencia de lo que sucede en otros ordenamientos jurídicos como el alemán o el italiano. El principio de economía procesal exigiría que no se tuviera que recurrir a nuevos procesos para declarar la misma inconstitucionalidad, pero además la declaración de inconstitucionalidad con nulidad alcanza no solo al precepto legal, sino también a la norma o mandato contemplado en ella, que es lo que se expulsa del ordenamiento con independencia de la forma que adopte $e^{28}$.

En nuestro caso concreto, la STC 31/2010 se debe valorar de forma expresa una consecuencia no prevista en la LOTC, que es precisamente el hecho de que se declara la inconstitucionalidad de preceptos estatutarios que mantienen relaciones de jerarquía y de respeto normativo con otros actos y normas de rango legal del propio ordenamiento autonómico. Se debe insistir en la idea de que el Estatuto de Autonomía es norma de cabecera de un ordenamiento propio, de forma que la nulidad, así como la interpretación conforme a la Constitución de los preceptos estatutarios implica un mandato que es susceptible de ser examinado como efecto vinculatorio específico de la sentencia del Tribunal Constitucional. En este sentido, es susceptible de generar consecuencias en idénticos mandatos de otras normas legales que mantienen relaciones de dependencia e inferioridad jerárquica con los preceptos declarados inconstitucionales del Estatuto de Autonomía.

\section{LA EJECUCIÓN DE LAS SENTENCIAS DECLARATIVAS DE INCONSTITUCIONALIDAD COMO MECANISMO DE GARANTÍA FRENTE A SU INCUMPLIMIENTO}

La autonomía procedimental de la jurisdicción constitucional no implica que se deba traspasar todas las reglas del proceso civil al constitucional (el art. 80 LOTC se remite a la supletoriedad de la LOPJ y de la LEC, pero se trata de una remisión parcial referida a materias concretas), a pesar de que las lagunas existentes y la interpretación de las prescripciones procesales de la LOTC es una función exclusiva del propio Tribunal Constitucional, que cuenta con competencia directa para fijar el alcance de las prescripciones procesales y decidir la integración de las lagunas. Esta autonomía procesal no se

28 Vid. Una argumentación similar en el ámbito del reglamento ejecutivo con cobertura de una ley declarada inconstitucional en CAAMAÑO, F., El control de constitucionalidad de disposiciones reglamentarias, CEC, Madrid, 1994, pág. 151. 
puede considerar un criterio para discutir el carácter jurisdiccional de su función, sino que se trata de una competencia pensada para suplir reglas procesales y adoptar reglas que se ajusten a las necesidades procesales de la jurisdicción constitucional, sin que en ningún caso pueda pensarse que el Tribunal Constitucional sustituye al legislador en sus funciones normativas. Contar con un ámbito para resolver lagunas en casos concretos no implica un espacio discrecional para la adopción de normas generales, sino una resolución de aspectos transitorios y circunstanciales para determinar los efectos y consecuencias de una declaración de inconstitucionalidad ${ }^{29}$. El principio de autonomía procesal permite la utilización de los criterios, principios y normas del Derecho Constitucional material para establecer la interpretación de las prescripciones procesales legales ${ }^{30}$. En nuestro caso concreto significa que, ante nuevos supuestos no previstos directamente en la LOTC, se deben buscar y plantear nuevos mecanismos de resolución de los posibles conflictos. La situación concreta puede significar que la STC 31/2010 es susceptible de engendrar incumplimientos por omisiones ante la obligación de la modificación del desarrollo normativo estatutario por incompatibilidad con la declaración de inconstitucionalidad o con los criterios interpretativos de preceptos estatutarios fijados por el Tribunal Constitucional, siendo necesario determinar las repercusiones y eventualmente hacer uso del principio de autonomía procesal.

El incumplimiento de una sentencia del Tribunal Constitucional abarca no solo el intento de reproducir una norma anulada, sino también una abierta desobediencia de la propia decisión del Tribunal. El proceso constitucional exige una leal colaboración de los diversos poderes públicos y una necesidad de mecanismos que garanticen el cumplimiento efectivo de las sentencias del Tribunal Constitucional, sin los cuales carecería de sentido el sistema de control constitucional de los actos de los poderes públicos, que eventualmente se articulan a través de los mecanismos de ejecución forzosa.

El art. 92 LOTC establece la competencia exclusiva del propio Tribunal Constitucional para disponer en la sentencia o actos posteriores el sujeto encargado de su ejecución y el modo de resolver las incidencias que se presenten. La influencia de la construcción alemana es clara en una simple comparación con el § 35 BVerfGG (Ley del Tribunal Constitucional Federal alemán). En la doctrina alemana se habla del Tribunal Constitucional como señor o dueño de la ejecución de sus decisiones (Herr der Vollstreckung) ${ }^{31}$, aun-

29 En el sistema de jurisdicción constitucional alemán hay una previsión expresa a favor del propio Tribunal Constitucional Federal para a la adopción de decisiones transitorias posteriores a la declaración de inconstitucionalidad en el $§ 32$ BVerfGG. Vid. sus consecuencias para la ejecución de sentencias declarativas de inconstitucionalidad en LAUMEN, S., Die Vollstreckungskompetenz nach § 35 BVerfGG. Eine systematische Darstellung, P. Lang Verlag, Frankfurt am Main-Berlin-Bern-Wien, 1997, pág. 97 y ss.

30 Sobre el alcance del principio y la influencia de la doctrina alemana en su concreción, BocANEgRA SIERRA, R., «Sobre el alcance objetivo de las sentencias del Tribunal Constitucional», en AAVV, Estudios sobre la Constitución Española. Homenaje al Profesor García de Enterría, Civitas, Marid, 1991, pág. 510-511; así como RoDríguez-Patrón, P., La Autonomía procesal del Tribunal Constitucional, Civitas, Madrid, 2003 y Rodríguez-PATRÓN, P., La potestad reglamentaria del Tribunal Constitucional, Iustel, Madrid, 2005.

31 Expresión popular en los trabajos de la materia originaria de DreHER, E., «Glanz und Elend der Staasgerichtbarkeit», NWJ, 1951, pág. 380 y GEIGER, W., Gesetz über das Bundesverfassungsgericht vom 12. März 1951. Kommentar, Vahlen, Berlin-Frankfurt a. M., 1952, § 35 Anm, 2. Esta expresión ha sido frecuentemente utilizada entre otros por Herzog, R., «Die Vollsreckung von Entscheidungen des Bundesverfassungsgerichts», Der Staat, 1965, nº 4, pág. 45 y SCHNEIDER, H.-P., «Die Vollstreckungskompetenz nach § 35 BVerfGG - ein 
que evidentemente sometido a las normas constitucionales y legales que establecen reglas competenciales y procedimentales sobre el sujeto y el modo de ejecutar sus decisiones, por lo que no es admisible la tesis de la total disponibilidad del Tribunal Constitucional sobre la ejecución de sus decisiones. En este sentido, no se pueden adoptar medidas arbitrarias o no relacionadas con la lógica y el sentido de la decisión concreta a ejecutar, aunque con la finalidad de garantizar la seguridad y la claridad jurídica. En definitiva, se establece a favor del propio Tribunal Constitucional la competencia general para exigir a todos los poderes públicos y eventualmente a los ciudadanos el cumplimiento de sus decisiones.

La constitucionalidad de este sistema de regulación de la ejecución de las sentencias del Tribunal Constitucional ha sido cuestionada sobre la base del principio del Estado de derecho por infracción del principio de separación de poderes y de tipificación o determinación de las medidas de ejecución ${ }^{32}$. Sin embargo, el propio tenor de la jurisdicción constitucional impide que otro órgano judicial pueda decidir en el ámbito de la competencia del Tribunal Constitucional, sobre todo en ámbitos exclusivos como el control de la constitucionalidad de la ley, o incluso que se puedan detallar medidas de ejecución en un ámbito en el que la flexibilidad es necesaria para adecuar y delimitar las consecuencias de las sentencias. En cualquier actividad de ejecución no es admisible la pretensión de la ampliación del contenido de la sentencia introduciendo hechos nuevos no analizados anteriormente ${ }^{33}$, ni tampoco es admisible que se afecte a intereses no presentes en el proceso principal $^{34}$, pero carece de sentido no autorizar al Tribunal Constitucional para que de un modo efectivo y rápido pueda suprimir la situación de inconstitucionalidad declarada en sus sentencias.

La regla de la jurisdicción constitucional es el cumplimiento voluntario de la sentencia por parte de los poderes públicos, a diferencia de lo que sucede en otras jurisdicciones, estimulado por la auctoritas del Tribunal Constitucional y el principio de lealtad constitucional $^{35}$, aunque la previsión de que puedan surgir incidentes y resistencias a las sentencias implica la regulación de un procedimiento de ejecución forzosa del art. 92 LOTC que permite decidir por el Tribunal Constitucional el sujeto y el modo del incidente de ejecución.

En esta cuestión resulta relevante diferenciar entre el cumplimiento de la sentencia del Tribunal Constitucional previsto en el art. 87.1 LOTC al que están obligados todos los poderes públicos entendido como mera realización material de las actuaciones ordenadas en el fallo llevadas a cabo por quién está obligado a cumplirlo, generalmente un ór-

Notverordnungsrecht des Budesverfassungsgericht?», NJW, 1994, pág. 2594, este último con la finalidad de diferenciar entre señor de la ejecución y señor de la Constitución como criterios diferentes en la actividad del Tribunal Constitucional. No obstante, téngase en cuenta que en otros sistemas constitucionales está prevista la separación de las funciones de declaración y de ejecución entre diferentes órganos estatales, vid. SCHÄFFER, H., «Die Exekution der Erkenntnisse des ósterrechisschen Verfassungsgerichtshofes», Österreichische Zeitschrift für öffentliches Recht, 1968, vol. XVIII, nº 2-3, pág. 186.

32 Sobre la posible inconstitucionalidad del § 35 BVerfGG en la doctrina alemana, vid. LAUMEN, S., op. cit., pág. 16-17.

33 ATC 232/1982 FJ 1

34 ATC 731/1984 FJ 2

35 Garronea Morales, A., op. cit., pág. 314 
gano administrativo, y la ejecución procesal prevista en el art. 92 LOTC como actividad orientada a garantizar el cumplimiento efectivo de la sentencia, que pone en juego la potestad del Tribunal Constitucional para ejecutar lo juzgado ${ }^{36}$. En definitiva, se trata de dos conceptos distintos previstos por la propia LOTC que tienen significados y consecuencias diferentes $^{37}$. En nuestro caso el cumplimiento material de la STC 31/2010 carece de relevancia sustancial, ya que es suficiente la mera publicación de la sentencia en el BOE. Sin embargo, la incidencia del efecto de vinculación en las obligaciones y deberes de los poderes públicos puede conllevar la necesidad de la adopción de medidas adicionales que garanticen la efectividad de la doctrina constitucional.

El incidente de ejecución que en todo caso es una categoría procesal implica que el Tribunal Constitucional pueda decidir el sujeto y el modo en que se debe garantizar el cumplimiento de la decisión adoptada, de forma que en función de un caso concreto se deberá determinar las necesidades de ejecución procesal de una sentencia del Tribunal Constitucional, que puede asumir directamente, cuando lo considere razonable y motivadamente necesario, la responsabilidad de la ejecución de sus decisiones. En este sentido, no se debe extrapolar de modo mecánico la doctrina procesal de la ejecución civil para decidir que las sentencias declarativas carecen de ejecución, a pesar de que se deba utilizar sustancialmente el incidente de ejecución propio del proceso civil previsto en la LEC $(\text { art. } 538 \text { y ss.) })^{38}$. En la jurisdicción constitucional no existe una pretensión autónoma de ejecución, ya que exclusivamente se dirige a la efectividad de una previa sentencia que es la causa determinante de una eventual prolongación de la actividad del Tribunal Constitucional $^{39}$.

La ejecución en la jurisdicción ordinaria se limita a las sentencias condenatorias en las que se reconoce un derecho o se fija una obligación de dar, hacer o no hacer, que posteriormente puede implicar la adopción de medidas para un cumplimiento efectivo de la resolución. Las sentencias declarativas que establecen una relación jurídica destinada a poner fin a una incertidumbre jurídica de las partes, pero sin una orden específica de prestación, o las sentencias constitutivas que modifican una relación jurídica preexistente, estableciendo una nueva relación jurídica en la propia resolución, tradicionalmente carecían de ejecución ${ }^{40}$. La aplicación de esta categoría a la sentencia constitucional de de-

36 Sobre la distinción entre cumplimiento y ejecución procesal de las sentencias del Tribunal Constitucional, vid. Garronea Morales, A., op. cit., pág. 316

37 Sobre la distinción entre ejecución y efecto se puede utilizar el trabajo de DraGo, G., L'exécution des décisions du Conseil Constitutionnel, Economica, Paris, 1991, pág. 15, referido a un sistema de control preventivo de constitucionalidad.

38 La reforma de la LOTC (LO 6/2007) introdujo una novedad en la regulación del incidente de ejecución ya que ha permitido su aplicación para anular cualquier resolución que contravenga las dictadas en el ejercicio de su jurisdicción, con ocasión de la ejecución de estas. En principio se trata de a medida para defender el ámbito de la jurisdicción constitucional, frente a las cuestiones de jurisdicción o competencia del Tribunal Constitucional planteadas por otros órganos jurisdiccionales, o para impedir que sus decisiones puedan ser enjuiciadas por otros órganos jurisdiccionales (art. 4.1 y 10.1.h LOTC). Sobre la posición institucional del Tribunal Constitucional, vid. Fernández Farreres, G., «La reforma de la ley orgánica del Tribunal Constitucional (Comentario a la Ley Orgánica 6/2007, de 24 de mayo)», en AAVV, Hacia una nueva jurisdicción constitucional. Estudios sobre la ley 6/2007, de 24 de mayo de reforma de la LOTC, Tirant lo blanch, Valencia, 2008, pág. 167 y ss.

39 Vid. Salas, J.-Palomino, V., «La ejecución de las sentencias del Tribunal Constitucional (Especial referencia a las relativas a la Administración)», DA, 1987, nº 209, pág. 92

40 Sobre los tres tipos de sentencias (declarativas, constitutivas y de condena) propias de la jurisdicción 
claración de inconstitucionalidad de normas legales es irrelevante, ya que implica unos efectos ex tunc y ipso iure, lo que ha facilitado que se le reconozca carácter meramente declarativo, a pesar que existe parte de la doctrina que considera que sus efectos son constitutivos a partir de la fecha de adopción.

En cualquier caso, la trasposición de estas categorías al Derecho procesal constitucional debe realizarse con todas las matizaciones necesarias y propias de la jurisdicción constitucional, teniendo en cuenta los efectos de las sentencias del Tribunal Constitucional exigidos a nivel constitucional y legal. En cierto modo, la exclusión de la ejecución de las sentencias declarativas de inconstitucionalidad se motiva exclusivamente en el carácter declarativo o constitutivo de dichas sentencias, sin comprobar que no todas las sentencias de inconstitucionalidad tienen consecuencias de nulidad, por lo que para dichos pronunciamientos que conllevan obligaciones de hacer o no hacer por parte de los poderes públicos se podría valorar posibles medidas de ejecución para dichos pronunciamientos y para los efectos de vinculación propios de todas las sentencias de control de constitucionalidad $^{41}$. El propio Tribunal Constitucional alemán nunca ha limitado la ejecución a las sentencias que impliquen prestaciones o abstenciones de los poderes públicos, ya que pueden ser necesarias cualquier tipo de medidas necesarias para el cumplimiento y realización de las decisiones jurídicas del Tribunal Constitucional ${ }^{42}$. De todas formas la ejecución de las sentencias declarativas de inconstitucionalidad no se dirige a la declaración de inconstitucionalidad en si misma considerada, sino a los comportamientos y prestaciones que deben realizar los poderes públicos vinculados para dotar de efectividad y realización a dicha decisión ${ }^{43}$, siendo precisamente en dicha esfera donde es susceptible de encontrarse elementos de singularidad para el caso de la STC 31/2010.

En este sentido, a pesar de que una declaración de nulidad de una norma inconstitucional representa una sentencia constitutiva, mientras que la resolución que establece la compatibilidad de una norma con la Constitución a partir de criterios interpretativos es una sentencia declarativa, siempre se puede considerar que el contenido de una sentencia de control de constitucionalidad es transformable en una obligación de acción para los poderes públicos, lo que puede implicar en caso de incumplimiento la adopción de medidas de ejecución como pueden las decisiones que se consideren necesarias, observables y aplicables a normas declaradas inconstitucionales y nulas ${ }^{44}$.

En un sentido similar, las sentencias de declaración de inconstitucionalidad que no conlleven la nulidad ipso iure, por ejemplo, sometiendo a condición o plazo la definitiva nulidad de la norma inconstitucional, implican necesariamente una nueva regulación del

civil y su traspaso a la jurisdicción constitucional, vid. un completo resumen en SCHÄFFER, H., op. cit., pág. 197 y ss.

41 Dentro de la doctrina alemana, sobre la ejecución de las sentencias declarativas y constitutivas en la jurisdicción constitucional, vid. GRAßHOF, M., Die Vollstreckung von Normenkontrollentscheidungen des Bundesverfassungsgerichts. Ein Beitrag zum Verbältnis zwischen Bundesverfassungsgericht und Gesetzgeber, P. Lang Verlag, Frankfurt am Main-Berlin-Bern-Wien, 2003, pág. 60 y ss.

42 VerfGE 6, 300 (303-304). Vid. Graßhof, M., op. cit., pág. 42.

43 En cierto sentido, no falta razón cuando se considera que el equivalente de las sentencias de condena del proceso civil son las sentencias declarativas en el proceso constitucional, vid. WEIß, H. A., Die Vollstreckung von Entscheidungen des Bundesverfassungsgerichts, Dissertation, Augsburg, 1976, pág. 7-8

44 GraßHOF, M., op. cit., pág. 307 
legislador antes del cumplimiento de la condición o plazo, con la consecuencia de una obligación concreta para el legislador y una inaplicabilidad de la norma inconstitucional tras el plazo o el efectivo cumplimiento de la condición. Este tipo de sentencia tiene la finalidad de evitar un despropósito mayor de posibilitar un periodo de validez o aplicación de la norma legal inconstitucional. En el fondo este tipo de declaración de inconstitucionalidad tiene efectos pro futuro y no ex tunc como las resoluciones de inconstitucionalidad con nulidad, lo que posibilita la adopción de medidas complementarias para garantizar el efectivo cumplimiento de las sentencias del Tribunal Constitucional y eventualmente su ejecución ${ }^{45}$.

Como podemos comprobar se da en nuestro sistema (y en otros sistemas) supuestos ya reconocidos en los que una aplicación mecanicista de los criterios de la ejecución procesal civil a la jurisdicción constitucional y, en concreto, al control de constitucionalidad de las leyes no son factibles, ya sea porque la declaración de inconstitucionalidad no siempre conlleva la nulidad de preceptos, ya sea porque el pronunciamiento del Tribunal Constitucional es transformable en obligaciones y deberes de los poderes públicos en el caso concreto.

Una trasposición mecanicista de las categorías anteriormente examinadas implicaría que las sentencias del Tribunal Constitucional carecerían de ejecución, ya que la mayoría son declarativas o constitutivas, sobre todo cuando afecta a la declaración de invalidez de normas jurídicas, y en las otras sentencias no serían necesarias, ya que los poderes públicos como destinatarios de las resoluciones adoptarían las medidas necesarias para dar un efectivo cumplimiento a las sentencias del Tribunal Constitucional. De todos modos, en la jurisdicción constitucional las sentencias declarativas o constitutivas, en general las sentencias del Tribunal Constitucional, no son puras en sus efectos, ya que los efectos y vinculaciones encierran obligaciones de hacer o no hacer de los poderes públicos implícitamente integradas en las resoluciones que son sobre las que recaen o pueden recaer en caso de incumplimiento los incidentes de ejecución posteriores ${ }^{46}$.

Nuestro Tribunal Constitucional ha considerado que en las sentencias declarativas de inconstitucionalidad de normas legales no existe ejecución, ya que el propio fallo consuma la expulsión del ordenamiento sin que se requiera intervención alguna posterior del legislador para derogarlas o modificarlas, o de cualquier otro órgano para asegurar la eficacia de su resultado ${ }^{47}$. Sin embargo, son necesarias una serie de matizaciones a esta doctrina para problemas que se conectan a la ejecución de este tipo de pronunciamientos, como pueden ser el alcance retroactivo sobre situaciones ya creadas o el efecto para el juez a quo en la cuestión de inconstitucionalidad ${ }^{48}$. Por otra parte, las sentencias declarativas vinculadas a una inconstitucionalidad se diferencian de las sentencias declarativas en el

45 Este planteamiento propio de la jurisdicción constitucional alemana ha sido frecuentemente utilizado, vid. Graßhof, M., op. cit., pág. 250, con abundantes indicaciones jurisprudenciales.

46 Esta especialización de la ejecución de las sentencias del Tribunal Constitucional fue reconocida por el propio Tribunal Constitucional desde sus primeras sentencias, vid. LAUMEN, S., op. cit., pág. 20. La necesidad de no aplicar de forma mecanicista la inejecución de las sentencias declarativas y constitutivas propias del proceso civil ya fue planteada por Herzog, R., op. cit., pág. 39

47 ATC 309/1987 FJ 2. Vid. Huelin Martínez de Velasco, J., «Comentario artículo 92 LOTC», en AAVV, Comentarios a la Ley Orgánica del Tribunal Constitucional, TC-BOE, Madrid, 2001, pág. 1376.

48 Garronea Morales, A., op. cit., pág. 318 
proceso civil en la fijación del petitum, pero también y sobre todo en las consecuencias del proceso que alcanza no solo a las partes sino con carácter general, vinculando a la decisión a los poderes públicos y fijando obligaciones que van más allá de la mera declaración de inconstitucionalidad. La ejecución comprende todas las medidas necesarias para dar cumplimiento y realización a la de cisión del Tribunal Constitucional, alcanzando la obligación a todos los poderes públicos, estatales o autonómicos.

El supuesto más llamativo es la reiteración, el mantenimiento de la lesión o la reproducción de igual comportamiento inconstitucional por el mismo sujeto y con el mismo objeto, teniendo en cuenta la dimensión objetiva de los pronunciamientos del Tribunal Constitucional es factible extender pro futuro la eficacia del fallo entre las partes a los supuestos de reiteración o mantenimiento de la lesión, resolviendo estos supuestos como incidentes de ejecución al tratarse de vicisitudes sucesivas de una misma relación jurídica, al reiterar o mantener la inconstitucionalidad ${ }^{49}$. El efecto de vinculación permite derivar una prohibición de repetir o mantener la norma declarada inconstitucional, o incluso su mandato, siempre que sea perfectamente comparables los supuestos y se pueda derivar una voluntad clara de fraude o de reiteración en contra de una previa, inmediata y directa decisión del Tribunal, siendo el factor tiempo una importante referencia. En cualquier caso, no se trata de un tema pacífico en la doctrina alemana ${ }^{50}$, precisamente por el riesgo de petrificación de una decisión jurisprudencial que puede variar en un futuro a través de un cambio de criterio.

De todos modos, la declaración de inconstitucionalidad de una norma legal implica una generalización de la decisión para impedir que vuelva a ser creada o aplicada dicha norma inconstitucional, pero el efecto de cosa juzgada no alcanza a los órganos estatales que no hayan sido parte en el proceso, es decir, dicho efecto no ocasiona el final de la validez de la norma declarada nula e inconstitucional. Esta necesidad de garantizar que los efectos de la declaración de inconstitucionalidad tenga carácter general y material alcanzando a todos los poderes públicos con unas consecuencias que son diferentes a los principios de la jurisdicción civil y a los términos de ejecución del proceso civil ${ }^{51}$, que se limitan exclusivamente a las partes del proceso principal. El control de constitucionalidad de las leyes es inseparable de las necesidades de generalización y de vinculación de la decisión jurisprudencial al poder público, lo que implica que estos efectos no tengan carácter procesal, a diferencia de lo que sucede con el efecto de cosa juzgada, sino carácter sustancial o material, determinables en obligaciones jurídicas susceptibles de ser ejecutadas.

En este sentido, la declaración de inconstitucionalidad de una norma legal implica también efectos pro futuro para impedir la adopción de actos de aplicación de la misma, sobre todo frente a actos administrativos o decisiones judiciales de aplicación, ya que en uno o en otro supuesto la revisión administrativa o judicial aparece como necesaria y razonable por suponer la adopción de un acto de incumplimiento no solo inconstitucional,

49 En cualquier caso, se trata de una doctrina muy casuística y dependiente del pronunciamiento del propio Tribunal Constitucional que aceptará la vía del incidente de ejecución o exigirá la apertura de un nuevo procedimiento dependiendo de las circunstancias del caso, vid. ATC 232/1982, STC 159/1987, ATC 134/1992. El problema es planteado por Garronea Morales, A., op. cit., pág. 320.

50 Un resumen de las posiciones en GraßHOF, M., op. cit., pág. 326-327.

51 Vid. Graßhof, M., op. cit., pág. 330-331. 
sino también ilegal. El problema reside en los actos legislativos y en la posible vinculación del legislador para determinar si siempre es necesaria la apertura de un nuevo proceso de declaración de inconstitucionalidad o si es reconducible en algunos supuestos a un acto de mera ejecución de una anterior sentencia del Tribunal Constitucional.

En cualquier caso, es conveniente resaltar que dejando al margen las posibles decisiones que se pueden adoptar para articular el efecto de vinculación de los poderes públicos en caso de incumplimiento de las sentencias del Tribunal Constitucional, lo cierto es que no cabe esperar excesivas repercusiones de un incidente de ejecución en caso de reiteración o mantenimiento de la lesión de inconstitucionalidad. El incumplimiento o los comportamientos negligentes frente al cumplimiento o ejecución de las sentencias del Tribunal Constitucional puede dar lugar a la adopción de sanciones coercitivas susceptibles de reiteración y repetición hasta el total cumplimiento (el art. 95.4 LOTC prevé multas coercitivas de 600 a 3000 por incumplimiento de los requerimientos del Tribunal Constitucional) y eventualmente a la exigencia de responsabilidad penal a través del delito de desobediencia previsto en el art. $410 \mathrm{CP}$, pero en este caso se debe tener en cuenta las especiales circunstancias de la jurisdicción constitucional, ya que no siempre es fácil realizar requerimientos concretos para un efectivo cumplimiento de las sentencias del Tribunal Constitucional.

Eventualmente los problemas de incumplimiento de una sentencia pueden abandonar la perspectiva de la utilización racional de los mecanismos jurídicos para la solución de controversias y derivar hacia conflicto políticos entre instituciones, difícilmente solucionables por mecanismos jurisdiccionales. En tales casos puede llegar a proceder la utilización de los mecanismos de coerción estatal previstos en el art. 155 CE $^{52}$. Esta utilización de la coerción de carácter extraordinario se debe realizar cuando el cumplimiento de las obligaciones de las Comunidades Autónomas no pueda ser efectuado y efectivo mediante los medios de control ordinarios. En general, el incumplimiento de las sentencias incurre dentro de los supuestos materiales de aplicación del art. 155 CE de forma mediata por incumplimiento de las obligaciones derivadas de la Constitución o de las leyes $^{53}$, o en el caso concreto del incumplimiento de las obligaciones previstas en la LOTC, pudiéndose incluir la desobediencia a las sentencias del Tribunal Constitucional ${ }^{54}$. La práctica obligaría a la adopción de los requerimientos oportunos por parte del Tribunal Constitucional, las eventuales sanciones coercitivas (art. 95.4 LOTC), la solicitud de eventuales responsabilidades penales y, en último extremo, solicitar la apertura de la adopción de las medidas oportunas que se puedan considerar necesarias en el marco del

52 Sobre el art. 155 CE, vid. BALlart, X., Coerció estatal i autonomies. L'article 155 de la Constitució, Escola d'Administració Pública de Catalunya, Barcelona, 1987; Calafell Ferrá, V. J., «La compulsión o coerción estatal (estudio del artículo 155 de la Constitución Española)», Revista de Derecho Político, 2000, n 48-49, pág. 99 y ss.; Vírgala Foruria, E., «La coacción estatal del artículo 155 de la Constitución», REDC, 2005, nº 73 , pág. 55 y ss.; GonZÁlez HernándeZ, E., «El control estatal sobre las Comunidades Autónomas: la reformas estatutarias y el supuesto de control extraordinario del artículo 155 CE. La fiscalización subsidiaria del Tribunal Constitucional», Parlamento y Constitución. Anuario, 2008, Núm. 11, pág. 161 y ss. A nivel comparado, vid. Gómez Orfanel, G., «La coerción federal en el Derecho comparado», Cuadernos de derecho público, 2005, n 26, pág. 41 y ss.

53 Sobre el incumplimiento de la Constitución o las leyes como supuesto material de aplicación del art. 155, vid. Calafell Ferrá, V. J., op. cit., pág. 108; Vírgala Foruria, E., op. cit., pág. 85 y ss.

54 El único autor que plantea abiertamente esta posibilidad es BALLART, X., op. cit., pág. 115-116. 
art. $155 \mathrm{CE}$, como pueden ser medidas de ejecución sustitutiva o subsidiaria de la actividad de las Comunidades Autónomas ${ }^{55}$, o incluso la restauración de efectos dejados de producir por una actividad ejecutiva desviada ${ }^{56}$.

En el caso de la STC 31/2010, cualquier medida que se deba adoptar en el sentido de vincular a dicha sentencia, las leyes de desarrollo de los preceptos estatutarios declarados inconstitucionales debe ser una consecuencia de una valoración del alcance retroactivo de la sentencia del Tribunal Constitucional en este supuesto. La declaración de inconstitucionalidad produce unos efectos de nulidad ex tunc o ab origine de la norma inconstitucional. Como nulidad de pleno derecho implica unas claras consecuencias para los actos derivados de su aplicación, control o de creación de nuevos preceptos con independencia de que tengan carácter legal o reglamentario, siempre que mantengan una relación directa con los preceptos estatutarios declarados inconstitucionales.

Las consecuencias de la retroactividad de la norma inconstitucional debe interpretarse en combinación con otros principios constitucionales como la seguridad jurídica, la buena fe, la prioridad del interés más general o el principio de igualdad ${ }^{57}$. Esta combinación ocasiona que si bien la ejecución de una sentencia declarativa de inconstitucionalidad no pueda tener consecuencias en relación con las normas legales pro futuro que siempre requerirán un nuevo proceso de control de constitucionalidad, incluso cuando mantengan relaciones de identidad por la posibilidad de cambio de criterio del Tribunal Constitucional. Sin embargo, en relación con las normas legales adoptadas en el pasado para la ejecución de las normas estatutarias declaradas inconstitucionales que no supongan hechos nuevos y existe una relación clara de identidad y casualidad, se pueden considerar vicisitudes anteriores de la misma relación jurídica enjuiciada en la sentencia y responden al mismo mandato declarado inconstitucional. Cualquier hecho nuevo requiere un proceso probatorio y de cognición, en definitiva, un nuevo proceso, pero los mismos hechos o mandatos declarados inconstitucionales, que pertenecen al pasado conocido y que han perdido su fundamentación y base estatutaria, deben quedar enmarcados en el mismo proceso. En este sentido, para dichos supuestos sería aplicable en caso de mantenimiento del incumplimiento del mandato jurisprudencial, las prescripciones de ejecución de las sentencias del Tribunal Constitucional, ya que se trata de una derivación del proceso principal. En este caso, el incidente de ejecución exclusivamente se centra en la discusión, conocimiento, verificación y valoración del incumplimiento y, en una segunda fase, en la adopción de medidas y resoluciones propiamente ejecutivas.

\section{EL EFECTO DE VINCULACIÓN DE LOS PODERES PÚBLICOS Y EL INCUMPLIMIENTO DE LAS SENTENCIAS DEL TRIBUNAL CONSTITUCIONAL}

El efecto de vinculación de los poderes públicos a las sentencias del Tribunal Constitucional debe tener un sentido propio no cubierto por los otros efectos y dirigido ex-

55 Vid. Calafell Ferrá, V. J., op. cit., pág. 131.

56 Vid. Vírgala Foruria, E., op. cit., pág. 101.

57 Garronea Morales, A., op. cit., pág. 367. 
clusivamente a garantizar el cumplimiento directo por parte de los poderes públicos de la decisión del Tribunal Constitucional. El incumplimiento o no observación de las declaraciones de inconstitucionalidad de normas legales por los órganos judiciales implica la apertura de una revisión judicial o constitucional, pero no requiere directamente de actos de aplicación de medidas de ejecución de sentencias, salvo para el cumplimiento de obligaciones directas derivadas de la propia sentencia. En general, no se puede ignorar que la aplicación de una norma legal declarada inconstitucional implica una acción arbitraria contraria al principio de constitucionalidad y legalidad en tanto que se ha adoptado un acto no autorizado de forma expresa por la ley, que es inválida, lo que tiene consecuencias y repercusiones en la actuación de los órganos aplicadores del Derecho, es decir, órganos judiciales y administrativos. Aún en el caso de que se admitiera que la declaración de inconstitucionalidad no precise ejecución ya que se modifica la situación jurídica directamente, no puede dar lugar a que la declaración de inconstitucionalidad pueda ser incumplida o ignorada sin ningún tipo de consecuencia.

Si el incumplimiento de la sentencia de declaración de inconstitucional se realiza por los órganos legislativos a través de una nueva ley, el efecto de vinculación carece de consecuencias, siendo necesario por regla general un nuevo proceso de control de constitucionalidad, ya que se trata de un acto normativo de carácter legal adoptado hacia el futuro. En cualquier caso, se debe examinar específicamente los casos de repetición o mantenimiento de norma declarada inconstitucional en el que siempre será necesaria una comparación para determinar si se está en presencia de un nuevo caso, es decir, si se ha producido una resistencia del legislador repitiendo o incluso manteniendo en esencia la norma declarada inconstitucional y nula.

De todos modos, es problemático determinar si el Tribunal Constitucional puede actuar sin petición previa, si las medidas de ejecución se deben adoptar de oficio, sin la apertura de un nuevo proceso de control de constitucionalidad. Aunque en realidad el art. 92 LOTC no establece que necesariamente la ejecución de las sentencias del Tribunal Constitucional sea un incidente de carácter rogado, no debe de ser considerado extraño que se limite la solicitud de medidas de ejecución de la STC 31/2010 a las partes del proceso principal. En el caso de que no sea posible por modificación de las circunstancias materiales o por nuevas regulaciones sustanciales la adopción de medidas de ejecución, será necesario un nuevo proceso de control de constitucionalidad. El efecto vinculatorio de las sentencias del Tribunal Constitucional encierra una obligación para todos los poderes públicos de abstención de reiterar o mantener el mismo comportamiento enjuiciado, es decir, de adoptar las mismas normas legales previamente examinadas en similares o idénticas circunstancias. Frente a esta obligación de abstención debería recaer el incidente de ejecución posterior ${ }^{58}$, que podría ser una derivación del efecto vinculatorio de los poderes públicos a la sentencia del Tribunal Constitucional o en determinadas circunstancias más estrictas una consecuencia del efecto de cosa juzgada ${ }^{59}$.

58 En sentido similar, GraßHOF, M., op. cit., pág. 347-348.

59 Sobre ambas posibilidades en la doctrina alemana, vid. GraßHOF, M., op. cit., pág. 354-356. En nuestra doctrina la reproducción de otra ley de un precepto inconstitucional no se considera un supuesto del efecto de cosa juzgada, vid. Gómez Montoro, A. J., «Comentario artículo 38 LOTC», op. cit., pág. 563. 
Otra matización que se debe realizar se centra en el hecho de que nos encontremos ante normas legales que poseen jerarquía sobre otras normas legales, como es el caso del Estatuto de Autonomía, para determinar si efectivamente se ven afectadas por las sentencias constitucionales que poseen una eficacia temporal y material basada en los efectos ex tunc y ipso iure, es decir, una nulidad radical y de forma automática, con lo que las repercusiones en otros preceptos de carácter legal implicarán que desaparecería el fundamento o cobertura legal que permitió la adopción en su momento de la declaración de inconstitucionalidad del Estatuto en tanto que norma de cabecera de un ordenamiento y de producción jurídica que fundamenta la validez de otros actos normativos secundarios en los que el legislador autonómica ha actuado de forma ejecutiva. En cualquier caso, no se trata de un nuevo examen de control de constitucionalidad, sino una consecuencia o derivación del proceso de control de constitucionalidad principal. En este sentido, el factor tiempo tiene una importante consideración, ya que los efectos hacia el pasado (y que tienen consecuencia desde la adopción del Estatuto hasta la publicación de la STC 31/2010) en relación al legislador son mucho más importantes y considerables que los efectos hacia el futuro. Los efectos hacia el pasado de la sentencia del Tribunal Constitucional son susceptibles de ser integrados en el incidente de ejecución, ya que no suponen nuevas decisiones del legislador susceptibles de ser controladas constitucionalmente, siempre que se cumpla la condición de que nos encontremos ante el mismo mandato declarado inconstitucional.

El tema de la vinculación del legislador a las sentencias del Tribunal Constitucional es dependiente de si se puede articular y demostrar la existencia de obligaciones de hacer por parte del legislador al margen del concreto fallo de la sentencia dentro de la fundamentación jurídica de la declaración de inconstitucionalidad. Las obligaciones de hacer del legislador solo son posibles mediante una norma concreta configurada para el destinatario, no una deducción de una obligación de carácter abstracto, ya que por lo demás las decisiones legislativas de carácter positivo solo las puede adoptar el propio legislador. Los efectos de vinculación no son una deducción, sino una consecuencia directa de la sentencia susceptible de ser articulada en ejecución.

En la doctrina alemana se han planteado unos efectos similares en vía de ejecución en relación con las denominadas normas paralelas, es decir, normas que no son objeto de examen en el control de constitucionalidad, pero que se corresponden con las disposiciones examinadas ${ }^{60}$. Esta problemática se plantea generalmente cuando una ley o norma legal de Land es declarada inconstitucional, pero en otros Länder existen normas o disposiciones iguales o similares. En nuestro sistema, la inconstitucionalidad por conexión o consecuencia a otros preceptos (art. 39.1 LOTC) supone la posibilidad de declarar inconstitucionales preceptos no impugnados de la misma ley objeto del control de constitucionalidad, es decir, la extensión de los efectos de la declaración de inconstitucionalidad con nulidad se encuentra limitada ${ }^{61}$.

60 Vid. Weiß, H. A., op. cit., pág. 125 y ss.; op. cit., pág. Laumen, S., op. cit., pág. 128-129 y GraßhOF, M., op. cit., pág. 336-337.

61 Vid. LAUmen, S., op. cit., pág. 91 y ss. En nuestra doctrina sobre la inconstitucionalidad por conexión o consecuencia, vid. Gómez Montoro, A. J., «Comentario artículo 39 LOTC», en AAVV, Comentarios a la Ley Orgánica del Tribunal Constitucional, TC-BOE, Madrid, 2001, pág. 603 y ss. 
Este tipo de inconstitucionalidad se plantea en supuestos en los que la norma a la que se extiende la inconstitucionalidad no fue incluida en el suplico de la demanda, siendo un deber, así como eventualmente una actuación de oficio del propio Tribunal su declaración ${ }^{62}$. La conexión se refiere a otros preceptos que participan del mismo régimen jurídico que el mandato declarado inconstitucional o en caso de materia distinta del mismo motivo que ha causado la inconstitucionalidad, mientras que la consecuencia se refiere a preceptos de la misma ley a los que se remiten los declarados inconstitucionales.

En cualquier caso, el art. 39.1 LOTC no permite deducir un supuesto similar al de las normas paralelas en el Derecho alemán, es decir, no permite declarar nula la misma norma reproducida en leyes de distintas Comunidades Autónomas. La extensión de la inconstitucionalidad siempre debe ser de la misma ley impugnada, siendo la única excepción planteada en nuestro sistema referida a preceptos idénticos en el caso de Textos Refundidos, es decir, norma inconstitucional incorporada con posterioridad a un Texto Refundido ${ }^{63}$.

En cualquier caso, este antecedente es operativo y puede ser válido en el caso de la STC 31/2010, ya que el supuesto es similar en el sentido de que el Estatuto de Autonomía en abstracto mantiene relaciones de jerarquía con otros actos y normas legales que en caso de que sean idénticas al mandato estatutario declarado inconstitucional debe producir los mismos efectos sin necesidad de una nueva declaración de inconstitucionalidad.

En estos casos de normas paralelas en nuestro sistema, la declaración de inconstitucionalidad solo es posible a través de un nuevo proceso de declaración de inconstitucionalidad, lo cual no significa que el efecto de vinculación a todos los poderes públicos no pueda desplegar sus propias consecuencias, es decir, el legislador se encuentra en una situación en la que en su propio ordenamiento hay normas que se encuentran en situación de ser declaradas inconstitucionales por lo que se podría desplegar el compromiso y la necesidad de modificar dichas decisiones para que desaparezcan los posibles perjuicios en los que se situarían los operadores jurídicos cuando estén en la necesidad de aplicar las normas en las que incide la declaración de inconstitucionalidad. El principio del Estado de Derecho obligaría al legislador autonómico a derogar las leyes inconstitucionales que existieran en su ordenamiento, siempre que esta fuera deducible de sentencias del Tribunal Constitucional que no les afectara directamente, ya que se pueden ver condicionados por vía interpretativa.

Por último, se debe examinar el incumplimiento de una sentencia de declaración de inconstitucionalidad de norma legal por parte de órganos ejecutivos. En este caso, evidentemente la aplicación de una norma declarada inconstitucional supondrá la posibilidad de extender la nulidad por derivación a los actos administrativos de aplicación de la misma, es decir, supone que los mecanismos de control administrativo, judicial o constitucional se puedan utilizar para eventualmente declarar la nulidad o inconstitucionalidad de un acto sin cobertura legal, aunque evidentemente se le deben aplicar el efecto

62 Vid. Gómez Montoro, A. J., «Comentario artículo 39 LOTC», op. cit., pág. 604.

63 Vid. Gómez Montoro, A. J., «Comentario artículo 39 LOTC», op. cit., pág. 605. En este sentido, en la STC 196/1997 FJ 4, se proyecta la declaración de inconstitucionalidad de los contenidos de una ley de refundición a los preceptos idénticos de un texto refundido. En la STC 194/2000 FJ 4, se extiende la declaración de inconstitucionalidad de un texto refundido que había incorporado la norma declarada inconstitucional con una forma distinta. 
de vinculación con sus consecuencias. El mecanismo de la ejecución forzosa de la sentencia judicial no puede estar cerrado, aunque la colaboración leal de los poderes públicos siempre es más efectiva que una coacción directa que no siempre posibilitará un cumplimiento efectivo.

En definitiva, la reparación de la ley o del Estatuto de Autonomía inconstitucional opera de forma inmediata con la sola intervención del Tribunal Constitucional y de forma mediata cuando se requiriera la intervención de otros órganos públicos. La reparación directa es una consecuencia de la declaración de inconstitucionalidad y, en consecuencia, de nulidad de preceptos estatutarios, que implica su expulsión del ordenamiento jurídico, que es el medio idóneo de reparación para el restablecimiento de la juridicidad vulnera$\mathrm{da}^{64}$. Uno de los efectos vinculados a la declaración de inconstitucionalidad de un precepto estatutario o legal es la exclusión de cualquier ultraactividad posterior de la ley inconstitucionalidad, lo que suponen unos plenos efectos retroactivos del Estatuto o la ley que generalmente se derivan a cualquier tema aplicación de la norma, pero que en nuestro caso se debe analizar a través de sus repercusiones en otras normas de carácter legal derivadas de preceptos declarados inconstitucionales de un Estatuto de Autonomía, sobre todo cuando mantenga dichos preceptos legales una relación directa con el mandato excluido por el Tribunal Constitucional.

La reparación mediata o indirecta es la que mayores repercusiones permitirá en nuestro caso, ya que ni la nulidad, ni la interpretación permiten reparar plenamente la inconstitucionalidad declarada, debido a que la declaración de inconstitucionalidad de preceptos del Estatuto conlleva de forma implícita un mandato y emplazamiento al legislador para que proceda a reparar todos los preceptos legales derivados de los declarados inconstitucionales, es decir, restaurar la integridad constitucional de forma plena y no mantener la inconstitucionalidad a través de preceptos legales o reglamentarios derivados. En si mismo la mayor responsabilidad para dar un cumplimiento efectivo de las sentencias de declaración de inconstitucionalidad corresponde al legislador que debe de adoptar leyes compatibles con la interpretación constitucional y el sentido de las sentencias de control de constitucionalidad. Dichas nuevas leyes de cumplimiento de las sentencias dará lugar a una efectiva vinculación de los órganos judiciales y ejecutivos que disminuirá las necesidades de revisión de sus sentencias, resoluciones y actos para garantizar el efectivo cumplimiento de las resoluciones del Tribunal Constitucional.

\section{VII.EL EFECTO DE VINCULACIÓN DE LOS PODERES PÚBLICOS A LAS SENTENCIAS INTERPRETATIVAS DEL TRIBUNAL CONSTITUCIONAL}

En general, las sentencias interpretativas del Tribunal Constitucional suelen ser desestimatorias, en el sentido que considera que el precepto impugnado es constitucional con una condición sustancial o material, es decir, si se interpreta en un determinado sentido o excluyendo una determinada interpretación, de modo que se establece en el co-

64 Vid. Jiménez CAmpo, J., op. cit., pág. 34-35 
rrespondiente fundamento jurídico de la sentencia la determinación o exclusión de la interpretación. En ocasiones y con los mismos efectos, aunque de forma más excepcional, el Tribunal Constitucional establece las denominadas sentencias interpretativas estimatorias, es decir, consideran que una norma impugnada es inconstitucional si se interpreta en un determinado sentido o fijando cual es el único sentido que actuaría como excepción a la declaración de inconstitucionalidad $^{65}$. No obstante, en la STC 31/2010 todos los preceptos estatutarios sometidos a una interpretación conforme a la Constitución responden al primer modelo, es decir, son sentencias interpretativas desestimatorias, considerando que son constitucionales siempre que se interpreten en el sentido planteado.

Tal como hemos analizado con anterioridad, los efectos ergaomnes son predicables de cualquier sentencia del Tribunal Constitucional, incluidas las desestimatorias de inconstitucionalidad y las interpretativas, siempre que no se limiten a la estimación subjetiva de un derecho vinculadas a procedimientos en amparo (art. 164 CE). La tendencia del Tribunal Constitucional ha sido incorporar, aunque no exenta de críticas ${ }^{66}$, de algún modo la ratio decidendi de las sentencias interpretativas al fallo, citando, por ejemplo, el fundamento jurídico respectivo en el que se fija el sentido correcto del precepto. En cualquier caso, la vinculación a las sentencias del Tribunal Constitucional no se realiza al resultado de la interpretación a través del fallo, sino a la real y correcta interpretación realizada en la correspondiente fundamentación jurídica.

En este sentido, la interpretación que realice el Tribunal de un precepto legal es inseparable del propio precepto, produciendo los efectos generales a través de la vinculación de jueces y tribunales ordinarios a las sentencias del Tribunal Constitucional, que deben interpretar y aplicar leyes y reglamentos de conformidad con las resoluciones del Alto Tribunal en todo tipo de procesos, es decir, no limitadas a las sentencias recaídas en procedimientos de inconstitucionalidad (art. 5.1 LOPJ $)^{67}$. Los efectos vinculantes de las sentencias interpretativas para los jueces implica que su quebrantamiento no solo sea considerado una conculcación de las competencias exclusivas del Tribunal Constitucional como juez de la ley, sino una infracción del sistema de fuentes conforme al cual se debe adoptar la resolución judicial (art. 1.7 CC) ${ }^{68}$. Ninguna sentencia del Tribunal Constitucional deja de ser interpretativa, por lo que se produce un efecto vinculatorio con carácter general predicable de la fundamentación de las sentencias en materia de control de constitucionalidad $^{69}$, que debe ser observado y cumplido también por el legislador en sus decisiones.

El problema principal de las sentencias interpretativas reside en la determinación de la vinculación del legislador tanto en relación a las normas legales anteriores a la adopción

65 Sobre la distinción entre sentencias interpretativas desestimatorias y estimatorias, vid. DíAz ReVoRIO, F. J., op. cit., pág. 54-55. Para una perspectiva de Derecho comparado sobre las sentencias interpretativas, vid. LÓPEz BOFILL, H., Decisiones interpretativas en el control de constitucionalidad de la ley, IVAP-Tirant lo blanch, Valencia, 2004, pág. 81 y ss. Para una visión crítica de las sentencias interpretativas y su alcance, vid. SANTOS Vijande, J. M., Doctrina y jurisprudencia del Tribunal Constitucional. Su eficacia respecto de los tribunales ordinarios, Comares, Granada, 1995, pág. 35 y ss.

66 Vid. Santos Vijande, J. M., op. cit., pág. 51 y ss. y 56 y ss.

67 Vid. Díaz Revorio, F. J., op. cit., pág. 109.

68 Vid. Santos Vijande, J. M., op. cit., pág. 111

69 Vid. Jiménez CAMPo, J., op. cit., pág. 30-31 
de la sentencia como en relación a las posteriores. En ambos supuestos necesariamente se debe realizar un nuevo control de constitucionalidad para el efectivo cumplimiento de la sentencia del Tribunal Constitucional. En nuestro caso concreto, la STC 31/2010 introduce numerosas interpretaciones de conformidad a la Constitución de los preceptos estatutarios, cuya relevancia y vinculación en relación con el legislador autonómico debe de ser objeto de un nuevo control, incluso a pesar de que los criterios interpretativos puedan ser operativos con carácter ex tunc. El contraste entre la interpretación conforme a la Constitución de los preceptos estatutarios y las normas legales afectadas debe ser el fruto de un análisis específico sin que pueda ser operativo de forma directa a través del proceso principal de control del Estatuto de Autonomía. Ahora bien, en situaciones con prescripciones claras debe ser el propio legislador autonómico el encargado de reparar la inconstitucionalidad de su obra sin provocar la adopción de decisiones posteriores del Tribunal Constitucional.

En las sentencias interpretativas el efecto de cosa juzgada material cobra una plena vigencia ante la eventualidad de que en el futuro recaigan nuevas impugnaciones sobre el mismo precepto (por ejemplo, a través de cuestiones de inconstitucionalidad), ya que se puede decidir una excepción a su tramitación en procesos posteriores ${ }^{70}$. En cualquier caso, en las sentencias interpretativas, como en las sentencias declarativas de inconstitucionalidad sin nulidad, siempre son posibles medidas de ejecución complementarias para garantizar el efecto vinculatorio a dichas decisiones y la realización material de las mismas.

Las sentencias del Tribunal Constitucional de carácter interpretativo tienen unos efectos que van más allá del caso concreto, de forma que la interpretación de preceptos del Estatuto de Autonomía o de leyes autonómicas de otras Comunidades no condicionadas directamente por la sentencia, sino que se encuentran vinculadas al contenido de las ratii decidendi, de forma que se condiciona su interpretación de la misma manera que si hubiera sido objeto de control. Este mismo efecto interpretativo condiciona a los preceptos que sean idénticos o similares a los declarados inconstitucionales y nulos de otros Estatutos de Autonomía, es decir, ocasionan los mismos efectos como si fuera una sentencia interpretativa, ya que no es posible plantear un recurso de inconstitucionalidad y la vía de la cuestión es de una difícil viabilidad.

\section{LA APLICACIÓN DE LOS EFECTOS VINCULANTES DE LOS PODERES PÚBLICOS A LA STC 31/2010}

Los efectos de la STC 31/2010 se deben diferenciar según afecte el pronunciamiento a una declaración directa de inconstitucionalidad con nulidad de determinados preceptos de forma completa o parcial (con incidencia a concretos incisos de los mismos) o constituyan una manifestación de sentencia interpretativa en la que se determina el sentido constitucional de un determinado precepto estatutario por el Tribunal Constitucional $^{71}$. La eficacia y el alcance de la sentencia varía por completo, tanto para las partes

70 Garronea Morales, A., op. cit., pág. 344

71 Sobre los efectos de la STC 31/2010 como sentencia interpretativa de forma crítica, vid. BERNADí 
del proceso o actores que adoptan o deben aplicar el Estatuto, como los efectos generales en relación a otros Estatutos que no han sido objeto de impugnación.

Los efectos de la STC se deben examinar en relación a la actividad de los diferentes ámbitos de actuación de los distintos poderes públicos ${ }^{72}$. En general los poderes autonómicos están vinculados como el resto de los poderes públicos, no siendo posible un incumplimiento de la sentencia sin las correspondientes consecuencias, que generalmente requiere nuevos pronunciamientos del Tribunal Constitucional o de la jurisdicción ordinaria, adoptando como referencia la doctrina constitucional asentada en la STC 31/2010 como precedente para casos idénticos o similares en otros Estatutos de Autonomía u otros ordenamientos autonómicos.

El Parlamento autonómico aparece como primer vinculado por la sentencia, sobre todo en relación con las normas legales de desarrollo estatutario directamente relacionados con los preceptos estatutarios declarados inconstitucionales. En este sentido, el Parlamento autonómico en aras a la seguridad jurídica y no plantear problemas de aplicación debería proceder a derogar aquellas leyes que incurran en inconstitucionalidad por derivación. Las reglas derivadas del principio constitucional del Estado de derecho exigirían un respeto escrupuloso de las sentencias del Tribunal Constitucional al órgano legislativo autonómico en un caso como el presente. En caso de inactividad, si es posible en relación a los plazos, los sujetos legitimados deberían plantear los correspondientes recursos de inconstitucionalidad. Si no es posible el planteamiento se debe esperar a examinar sus consecuencias en el supuesto de su aplicación administrativa o judicial, es decir, si tiene efectos externos la aplicación de leyes inconstitucionales por derivación se podrá aplicar los mecanismos propios de su control. En algún caso concreto, incluso sería posible intentar la aplicación del incidente de ejecución cuando nos encontremos ante el mismo e idéntico mandato de declaración de inconstitucionalidad de un precepto estatutario.

En cualquier caso, los efectos más previsibles desde un punto de vista constitucional se sitúan en el ámbito de la aplicación del contenido de la sentencia. El Poder Judicial ante una Sentencia del Tribunal Constitucional que declara la inconstitucionalidad o una sentencia interpretativa está directamente vinculado a su contenido en virtud del art. 5.1 LOPJ que obliga incluso a su utilización como precedente en sus respectivas sentencias, por lo que no se pueden, ni deben desviar de su contenido a riesgo de revisión o incurrir en las correspondientes responsabilidades. En el caso de dudas o de aplicación de leyes que no han sido objeto de declaración expresa de inconstitucionalidad deben de plantear la correspondiente cuestión de inconstitucionalidad, sobre todo en casos no excesivamente claros o que afectan a normas o actos normativos de carácter legal. La hipótesis de supuestos claros no puede tener relevancia en nuestro caso, ya que se puede referir a pre-

GIL, X., « ¿Competencias desactivadas? Consideraciones sobre la denominada sentencia oculta», Revista Catalana de Dret Públic, $n^{\circ}$ especial Sentencia sobre el Estatuto, 2010, pág. 1 y ss.

72 También plantea un análisis de la STC 31/2010 a partir de los efectos de vinculación de los poderes públicos, García RoCA, J., «De las competencias en el Estatuto de Cataluña según la STC 31/2010, de 28 de junio: una primera lectura integradora», El Cronista del Estado Social y Democrático de Derecho, 2010, octubre, $\mathrm{n}^{\circ}$ 15, pág. 55. Para una valoración de las funciones del Tribunal Constitucional en el control de constitucionalidad de un Estatuto de Autonomía, vid. Ferreres Comella, V., «El Tribunal Constitucional ante el Estatuto», Revista Catalana de Dret Públic, no especial Sentencia sobre el Estatuto, 2010, pág. 1 y ss. 
ceptos que no son objeto de aplicación judicial por un contenido institucional estricto y sin efectos en otros tipos de procedimientos o a incisos de preceptos declarados nulos, generalmente conectados a efectos meramente interpretativos de reglas de distribución de competencias que no se pueden extender a otros supuestos del propio ordenamiento autonómico, debido a que generalmente declara la competencia como atribución del Estado o de los órganos constitucionales estatales.

La vinculación a sentencias interpretativas por parte del Poder Judicial recibe un tratamiento similar en el sentido de que la vinculación implica que cualquier supuesto en el que deban aplicar los preceptos objeto de aplicación u otros de desarrollo con similar contenido deberá ser objeto de cumplimiento del correspondiente mandato interpretativo o precedente y del contenido de la sentencia. El incumplimiento también puede ser objeto de revisión por los propios órganos jurisdiccionales en una instancia superior o eventualmente a través del recurso de amparo por quebrantamiento de jurisprudencia del Tribunal Constitucional, si es que se produce una infracción de derechos fundamentales que generalmente se podrá interrelacionar con el derecho a la tutela judicial efectiva (art. 24.1 $\mathrm{CE})^{73}$. El supuesto más estricto es un tanto impensable, debido a que la aplicación de normas inconstitucionales por los órganos judiciales es claramente un supuesto que genera indefensión a los partes procesales, pero se debe insistir en la idea de que se puede plantear siempre que sea posible la aplicación de los preceptos estatutarios declarados inconstitucionales dentro del proceso principal.

En relación con el supuesto de aplicación judicial de preceptos de leyes de desarrollo estatutario relacionada con preceptos estatutarios declarados inconstitucionales debería interrelacionarse directamente con el planteamiento de una cuestión de inconstitucionalidad, que en este supuesto no debería resultar dudosa su adopción. Si las leyes correspondientes no han sido derogadas y se plantea un supuesto de su aplicación judicial, no cabe otra posibilidad que su declaración de inconstitucionalidad posterior ya que no han sido objeto de expreso control de constitucionalidad, sobre todo cuando afecta a interpretaciones conforme a la Constitución de preceptos estatutarios.

La vinculación de los poderes públicos autonómicos, sobre todo el poder ejecutivo es directa, pero también la de los órganos estatutarios como el Consejo de Garantías Estatutarias o el Síndic de Greuges. Si se realiza una actuación conforme a los preceptos declarados inconstitucionales y nulos, la actuación implica, entre otras posibles consecuencias, una actuación en un ámbito para el que no se es competente, por lo que siempre se puede plantear un conflicto de competencias positivo, ya que las competencias no especificadas corresponden al Estado central o a los correspondientes órganos en el ejercicio de sus funciones constitucionales o legales. La aplicación de la cláusula residual (art. 149.3 CE) obligaría al Estado a plantear un conflicto de competencia positivo, ya que se están adoptando decisiones en ámbitos para los que ya no son competentes las autoridades autonómicas. Un ejemplo típico podría ser la adopción de normas reglamentarias de desarrollo y ejecución de las leyes afectadas de inconstitucionalidad por derivación.

73 No obstante, en ocasiones se ha criticado que el quebrantamiento de la doctrina constitucional del Tribunal Constitucional se pueda considerar un supuesto de infracción del art. 24.1 CE, vid. SANTOS VIJANDE, J. M., op. cit., pág. 105 y ss., en especial pág. 113-114. y pág. 126 y ss. 


\section{LA INCIDENCIA CONCRETA DE LA STC 31/2010 EN LA NORMATIVA LEGAL AUTONÓMICA DE DESARROLLO ESTATUTARIO}

Los efectos de las sentencia del Tribunal Constitucional en relación a la normativa de desarrollo legislativo del Estatuto se deben diferenciar según afecte el pronunciamiento a preceptos con carácter declarativo de la inconstitucionalidad con nulidad y expulsión del ordenamiento jurídico o a preceptos concretos con carácter interpretativo ${ }^{74}$. Con anterioridad estos efectos se deben concretar en exclusiva con actos normativos de carácter legal aprobados por la Generalidad con posterioridad a la entrada en vigor del Estatuto, es decir, básicamente actos normativos aprobados durante la última legislatura, que pueden verse condicionados por la presente declaración de inconstitucionalidad de preceptos estatutarios que les sirvieron directamente en su existencia y contenido al tratarse de una norma de cabecera y de producción normativa, que ha sido declarada inconstitucional y que genera efectos temporales hacia el pasado.

Si estamos ante un precepto estatutario que ha sido objeto de una interpretación conforme en un determinado fundamento jurídico de la sentencia, el contraste y los efectos se debe realizar de un modo concreto y específico, es decir, siempre se va a requerir un nuevo pronunciamiento para determinar si efectivamente la ley de desarrollo legislativo aprobado por el Parlamento de Cataluña o por la autoridad con potestad legislativa incurre en la inconstitucionalidad interpretativa planteada por el Tribunal Constitucional. Este será el supuesto más numeroso de los planteados y no solo porque mayoritariamente la sentencia del Estatuto tiene carácter interpretativo, sino porque también muchas de las declaraciones de inconstitucionalidad más que efectos jurídicos directos sobre el ordenamiento van a tener consecuencias en realidad sobre la normativa estatal o la expulsión del ordenamiento del precepto estatutario no condiciona materialmente ningún acto normativo de carácter legal de la Generalidad. No es extraño que haya sido considerado que la utilización de sentencias interpretativas ha sido en cierto modo un sistema de cerrar el debate en falso ${ }^{75}$, ya que se requerirá necesariamente un nuevo pronunciamiento sobre la mayoría de la normativa de desarrollo para determinar si se adecua o no a la interpretación conforme fijada por el Tribunal Constitucional.

74 Para una visión general del significado material y formal de la STC 31/2010, vid. CASTELLÀ ANDREU, J. M., «La Sentencia del Tribunal Constitucional 31/2010, sobre el Estatuto de Autonomía de Cataluña y su significado para el futuro del Estado Autonómico», Fundación Ciudadanía y Valores, www .funciva.org, Septiembre 2010, pág. 4 y ss.; Elías Méndez, C., «Aproximación a la Sentencia del Tribunal Constitucional sobre el Estatuto de Autonomía de Cataluña: nación, lengua, derechos y competencias «, Revista General de Derecho Constitucional 10 (2010), pág. 1 y ss.; BlanCo Valdés, R. L., «El Estatuto catalán y la sentencia de nunca acabar», Claves de Razón Práctica, 2010, n 205, pág. 4 y ss.; Carreras Serra, F. de, «¿Es constitucional el Estatuto de Cataluña», Claves de Razón Práctica, 2010, n 206, pág. 10 y ss.; AlberTí Rovira, E., «La Sentencia 31/2010: Valoración general de su impacto sobre el Estatuto y el Estado de las Autonomías», Revista Catalana de Dret Públic, $n^{\circ}$ especial Sentencia sobre el Estatuto, 2010, pág. 1 y ss.; Ferret JaCAs, J., «Una visión global de la Sentencia», Revista Catalana de Dret Públic, no especial Sentencia sobre el Estatuto, 2010, pág. 1 y ss.; ToRnOs MAS, J., «Valoración general», Revista Catalana de Dret Públic, $n^{\circ}$ especial Sentencia sobre el Estatuto, 2010, pág. 1 y ss.; Viver Pi-Sunyer, C., «Los efectos jurídicos de la Sentencia sobre el Estatuto», Revista Catalana de Dret Públic, $n^{0}$ especial Sentencia sobre el Estatuto, 2010, pág. 1 y ss.

75 Vid. Blanco Valdés, R. L., op. cit., pág. 17-18 y García Roca, J., op. cit., pág. 60-61 
En este sentido, es conveniente resaltar los principales casos en los que pueden plantear conflictos las leyes de desarrollo de un precepto estatutario que ha sido objeto de interpretación por la STC 31/2010 y que, en general, aunque no en todos los supuestos, ya han sido objeto de la presentación de un recurso de inconstitucionalidad por parte de alguno de los órganos o sujetos legitimados.

En primer lugar, procede analizar brevemente la Ley 30/2010, de 3 de agosto, de veguerías, que tiene entre otros objetos regular y determinar la división territorial de Cataluña en veguerías y establecer el régimen jurídico de los consejos de veguería, pero también establecer la transición de las diputaciones provinciales a los nuevos consejos de veguería, que se realizar a través de un procedimiento de subrogación regulador en los artículos 31 y 32, así como una sustitución nominal de las Diputaciones Provinciales por veguerías a pesar de que no coinciden en número a través de las diversas disposiciones transitorias de la mencionada ley, por lo que se realiza una previsión de modificaciones en la normativa estatal. En el momento del presente análisis esta ley no ha sido impugnada, pero tanto el art. 90 EAC como el art. 91 EAC fueron objeto de una interpretación conforme en el sentido de considerar que la veguería como «gobierno local» en el ámbito de la cooperación entre municipios implica una clara analogía con la definición que hace la Constitución de la provincia como entidad local determinada por la agrupación de municipios. Ahora bien la definición de la provincia como entidad local cuya existencia está garantizada por la Constitución no excluye la existencia de otras entidades de gobierno supramunicipal, siempre y cuando, claro está, se respete la existencia y autonomía de las provincias, de modo que el Tribunal Constitucional considera que «así interpretado, el art. $90 \mathrm{EAC}$ no es contrario a la Constitución» ${ }^{76}$. De este modo, se puede considerar que la Constitución no impide que, en Cataluña, las provincias pasen a llamarse «veguerías» ni que las diputaciones - como órganos de gobierno de las provincias - sean sustituidas por los consejos de veguerías. No obstante, el legislador autonómico está sujeto a los límites que, en esta materia, se derivan de la Constitución, es decir, corresponde al legislador estatal determinar la composición de los consejos de veguería, el modo de elección de sus miembros y fijar las competencias de las veguerías en el plano local, pero además si se entiende que «veguería» es sinónimo en Cataluña de «provincia», el legislador autonómico no puede crear, modificar o suprimir veguerías ni desarrollar su régimen jurídico, ya que la Constitución determina que es el Estado, mediante ley orgánica, el encargado de fijar los límites provinciales ${ }^{77}$. Evidentemente si la regulación de la transición de las diputaciones provinciales al nuevo régimen de veguerías, el aumento del número de veguerías respecto al de provincias existentes en Cataluña, respeta o no las directrices fijadas en los respectivos fundamentos jurídicos de la sentencia, se requiere un nuevo pronunciamiento de control de constitucionalidad al tratarse de un parámetro meramente interpretativo ${ }^{78}$.

76 STC 31/2010 FJ 40. Sobre las veguerías y el alcance de la STC 31/2010, vid. GaLÁN GALÁn, A.- GraCia Retortillo, R., «Incidencia de la Sentencia 31/2010 del Tribunal Constitucional en la regulación del Estatuto de Autonomía de Cataluña sobre los gobiernos locales», Revista Catalana de Dret Públic, no especial Sentencia sobre el Estatuto, 2010, pág. 5 y ss.

77 STC 31/2010 FJ 41

78 Sobre los efectos de la STC 31/2001 en la temática, vid. FuENTES y GASÓ, J. R., «El régimen local de Cataluña y la viabilidad de articulación de una planta política y administrativa propia después de la Sentencia 
Un segundo ejemplo de situación en la que se requiere un nuevo pronunciamiento del Tribunal Constitucional lo constituye la impugnación de la Ley 22/2010, de 20 de julio, del Código de consumo de Cataluña, sobre la que se ha presentado un recurso de inconstitucionalidad por parte del Defensor del Pueblo y el Grupo Popular del Congreso, y de la Ley 20/2010, de 7 de julio, del cine, impugnada mediante recurso de inconstitucionalidad por el Grupo Popular del Congreso. La lógica de estas impugnaciones responden a los mismos motivos, es decir, se regulan derechos lingüísticos de las personas consumidoras con el correspondiente deber de disponibilidad lingüística en las relaciones privadas, o se establece la obligación de distribuir un porcentaje elevado de copias de cintas cinematográficas en versión de lengua catalana que es también una consecuencia del deber de disponibilidad lingüística en las relaciones privadas, así como un régimen sancionatorio en ambos supuestos en el caso de incumplimiento de dichas obligaciones y deberes. En este sentido, se debe realizar un contraste con el art. 34 EAC que fue objeto de una interpretación conforme por parte del Tribunal Constitucional que considera que el deber de disponibilidad lingüística de las entidades privadas, empresas o establecimientos abiertos al público no puede significar la imposición a éstas, a su titular o a su personal de obligaciones individuales de uso de cualquiera de las dos lenguas oficiales de modo general, inmediato y directo en las relaciones privadas, toda vez que el derecho a ser atendido en cualquiera de dichas lenguas sólo puede ser exigible en las relaciones entre los poderes públicos y los ciudadanos ${ }^{79}$. Como se puede deducir con facilidad en este supuesto nos volvemos a encontrar en el caso de un fundamento interpretativo de forma que para determinar la inconstitucionalidad de normas legales de aplicación y desarrollo de los correspondientes preceptos estatutarios es necesario un posterior control de constitucionalidad.

Un último ejemplo de la necesidad de un nuevo pronunciamiento lo puede constituir la Ley 4/2010, de 17 de marzo, de consultas populares por vía de referéndum sobre la que se ha anunciado la presentación de un recurso de inconstitucionalidad por parte del Gobierno. En general, la filosofía y el objeto de esta ley se basa en regular el régimen jurídico, el procedimiento, el cumplimiento y la convocatoria por la Generalidad o por los ayuntamientos de las consultas populares por vía de referéndum, como instrumento de participación directa para determinar la voluntad del cuerpo electoral sobre cuestiones políticas de especial trascendencia con las garantías propias del procedimiento electoral. Ahora bien el Tribunal Constitucional en relación con el art. 122 EAC determinó que en dicho precepto caben consultas populares no referendarias, es decir, en la expresión «cualquier otro instrumento de consulta popular» no se comprende el referéndum, de forma que el art. $122 \mathrm{EAC}$ no es inconstitucional interpretado en el sentido de que la excepción en él contemplada se extiende a la institución del referéndum en su integridad, y no sólo a la autorización estatal de su convocatoria ${ }^{80}$. En este sentido, determinar si la lógica de las consultas populares por vía de referéndum prevista por la mencionada ley constituyen o no un referéndum debe ser objeto de un nuevo pronunciamiento del Tri-

del Tribunal Constitucional de 28 de junio de 2010», Revista Catalana de Dret Públic, $n^{o}$ especial Sentencia sobre el Estatuto, 2010, pág. 3 y ss.

79 STC 31/2010 FJ 22

80 STC 31/2010 FJ 69 
bunal Constitucional por tratarse de una interpretación conforme que debe ser de nuevo contrastada, que en caso de ser aceptada alcanzaría a la práctica totalidad de la ley ${ }^{81}$.

Los siguientes ejemplos que se van a analizar responden a la lógica de contrastar leyes de desarrollo estatutario con una incidencia indirecta en el precepto parcialmente declarado inconstitucional del Estatuto, con lo que en la práctica se debe realizar un nuevo control de constitucionalidad de dichas leyes, ya que sus consecuencias se deben analizar como si se tratará de una sentencia interpretativa. En estos casos la vinculación del legislador se produce como consecuencia de una interpretación conforme sin poder derivar efectos directos, a pesar de que el parámetro lo va a constituir la interpretación realizada para declarar inconstitucional y nulo un precepto estatutario.

Un primer ejemplo de este supuesto afecta a la impugnación realizada por el Defensor del Pueblo frente a la Ley 10/2010, de 7 de mayo, de acogida de las personas inmigradas y de las regresadas a Cataluña, que afecta al precepto regulador de las competencias lingüísticas básicas de estas personas sobre todo en relación a la preferencia de la adquisición de las competencias básicas en lengua catalana, ya que el servicio administrativo autonómico de primera acogida, terminada la formación en lengua catalana, debe ofrecer la formación para adquirir las competencias básicas en lengua castellana a las personas que hayan alcanzado la adquisición de competencias básicas en lengua catalana y que lo soliciten o lo requieran. El precepto no plantea problemas en relación con la competencia exclusiva del Estado en materia de inmigración (art. 149.1.2 CE), ya que la Comunidad Autónoma solo tiene competencias en base a otras materias sectoriales (asistencia social, competencia ejecutiva en materia de legislación laboral ${ }^{82}$. Ahora bien el contraste se debe realizar con la declaración de inconstitucionalidad del carácter preferente de la lengua catalana (art. 6.1 EAC). En este sentido, el Tribunal Constitucional afirmó que si de dicho precepto se pretende deducir que únicamente el catalán es lengua de uso normal y preferente del poder público, siquiera sea sólo del poder público autonómico, se estaría contradiciendo una de las características constitucionalmente definidoras de la oficialidad lingüística, que es que las lenguas oficiales constituyen un medio normal de comunicación en y entre los poderes públicos y en su relación con los sujetos privados, con plena validez y efectos jurídicos. Toda lengua oficial es, por tanto también allí donde comparte esa cualidad con otra lengua española-, lengua de uso normal por y ante el poder público, de forma que lo es el castellano por y ante las Administraciones públicas catalanas, que, como el poder público estatal en Cataluña, no pueden tener preferencia por ninguna de las dos lenguas oficiales ${ }^{83}$. La mencionada ley establece un criterio de preferencia en las competencias básicas ligüísticas que ofrecerá un servicio administrativo autonómico, de forma que se debe realizar un control de constitucionalidad basado precisamente en un precepto estatutario parcialmente declarado in-

81 Sobre el alcance de la doctrina del Tribunal Constitucional en materia de consultas populares, vid. CASTELlà ANDREu, J. M., «La competencia en materia de consultas populares por la vía de referéndum en la Sentencia 31/2010 sobre el Estatuto de Autonomía de Cataluña», Revista Catalana de Dret Públic, $n^{\circ}$ especial Sentencia sobre el Estatuto, 2010, pág. 3 y ss.; MARTín, E., «Comentario a la STC sobre el Estatuto. Competencia en materia de consultas populares (art. 122)», Revista Catalana de Dret Públic, $n^{0}$ especial Sentencia sobre el Estatuto, 2010, pág. 1 y ss.

82 STC 31/2010 FJ 83

83 STC 31/2010 FJ 14 
constitucional y nulo, pero sus consecuencias indirectas en otra ley debe ser operativas como interpretación conforme y no directamente una derivación de la misma.

Otro ejemplo similar al planteado hace referencia a la impugnación por parte del Defensor del Pueblo de la Ley 24/2009, de 23 de diciembre, del Síndic de Greuges, centrada básicamente en la comprobación del alcance de las competencias del Síndic para controlar la actividad de la administración local y en la atribución de la condición de Autoridad Catalana para la Prevención de la Tortura y de otros Tratos o Penas Crueles, Inhumanos o Degradantes con repercusiones en la actuación de cualquier administración pública. En este caso, se debe realizar un nuevo control de constitucionalidad de los preceptos impugnados, ya que se había declarado parcialmente inconstitucional y nulo el art. 78.1 EAC en el sentido de atribuir con carácter exclusivo la supervisión de la actividad de la Administración de la Generalitat y la local en Cataluña. El Tribunal Constitucional declaró inconstitucional por infracción del art. 54 CE que el Sindic de Greuges supervise con carácter exclusivo la actividad administrativa autonómica, ya que la actividad del Defensor del Pueblo, como alto comisionado de las Cortes Generales, implica la perfecta cobertura de las garantías de los derechos fundamentales de la CE que debe proyectarse sobre todas las administraciones públicas, dado que las referencias a la «Administración» de los arts. 54, 103 y $106 \mathrm{CE}$, comprenden todo poder público autonómico o central distinto de la legislación y de la jurisdicción ${ }^{84}$.

Por último, se debe proceder al análisis del supuesto más conflictivo, que se refiere al art. 18 de la Ley 2/2009, de 12 de febrero, del Consejo de Garantías Estatutarias, en relación con los dictámenes vinculantes previstos en el art. 76.4 EAC que establecía que «Los dictámenes del Consejo de Garantías Estatutarias tienen carácter vinculante con relación a los proyectos de ley y las proposiciones de ley del Parlamento que desarrollen o afecten a derechos reconocidos por el presente Estatuto». Este precepto fue declarado inconstitucional, nulo y expulsado del ordenamiento jurídico en su conjunto sin mantener ningún tipo de operatividad. De este modo, intentar desplegar algún efecto del art. 18 de la mencionada Ley implicaría posibilitar la aplicación y extensión de la sentencia a dicho supuesto mediante un incidente de ejecución. En este punto concreto el Estatuto actúa como norma de producción jurídica, autorizando directamente la adopción de dicho precepto, que es una continuidad inseparable del art. 76.4 EAC, de forma que el mismo mandato contenido en la sentencia del Tribunal Constitucional es susceptible de ser ejecutado de forma directa en relación con el art. 18 de la Ley del Consejo de Garantías Estatutarias. Conviene recordar que el art. 76.4 EAC fue declarado inconstitucional porque suponía como control preventivo una limitación de la autonomía parlamentaria y de los derechos de participación política reconocidos en el artículo 23 CE no amparada por la Constitución y su configuración se realizaba en términos materialmente equivalentes a un control jurisdiccional sobre normas legales enteramente perfeccionadas en su contenido, perjudicándose el monopolio de rechazo de las normas con fuerza de ley reservado por el art. $161 \mathrm{CE}$ al Tribunal Constitucional ${ }^{85}$.

84 STC 31/2010 FJ 33. Sobre el alcance de las competencias del Síndic tras la STC 31/2010, vid. VINTRÓ Castells, J., «La exclusividad del Síndic de Greuges», Revista Catalana de Dret Públic, $n^{\circ}$ especial Sentencia sobre el Estatuto, 2010, pág. 3-4.

85 STC 31/2010 FJ 32. Sobre los dictámenes vinculantes y su declaración de inconstitucionalidad, vid. 
Por último, también se debe destacar y concluir que frente a la normativa de desarrollo autonómica del Estatuto si es posterior a la Sentencia del Tribunal Constitucional necesariamente se debe realizar un nuevo pronunciamiento en materia de control de constitucionalidad. Si está normativa ha sido aprobada con anterioridad a la Sentencia se debe analizar materialmente en el caso concreto, pero en general si afecta a una interpretación conforme a la Constitución necesariamente se debe realizar un nuevo control de constitucionalidad, y lo mismo sucede en el caso de una declaración de inconstitucionalidad y nulidad parcial de un precepto del Estatuto, ya que se requiere realizar un nuevo examen, siendo la labor interpretativa específica del caso. No obstante, si nos encontramos ante un precepto que en su integridad ha sido declarado inconstitucional y nulo, dada la característica del Estatuto como norma de cabecera y atributiva de la concreta competencia, implica que todos los preceptos subordinados a dicha norma concreta expulsada en su integridad del ordenamiento, incurran en el mismo mandato de inconstitucionalidad, es decir, en su existencia depende de un precepto inexistente con carácter retroactivo, con una sentencia con plenos efectos hacia el pasado y que en todo caso como efecto vinculatorio simplemente debe ser objeto de ejecución.

Como se puede comprobar no es que estemos ante un supuesto que afecte a numerosos preceptos, ya que solamente es hipotéticamente aplicable a un supuesto concreto que sería el art. 18 de la Ley del Consejo de Garantías Estatutarias, ya que en esencia la STC 31/2010 es una sentencia de carácter interpretativo o declarativo de inconstitucionalidad parcial por lo que la extensión de sus efectos a otras normas requiere casi siempre de un nuevo proceso de control de constitucionalidad. Otra cosa distinta es la vinculación de los efectos a los procesos de aplicación en los que el control y la vinculación a los poderes judicial y ejecutivo que como ya ha sido analizado merecen otra consideración.

\section{LA EXTENSIÓN DE LA APLICACIÓN DE LOS EFECTOS DE LA STC 31/2010 A LOS PRECEPTOS IDÉNTICOS O SIMILARES EN LOS OTROS ESTATUTOS DE AUTONOMÍA}

En relación a los preceptos idénticos, casi idénticos o similares de los otros Estatutos de Autonomía se debe determinar el modo en que afecta de forma específica la Sentencia del Tribunal Constitucional sobre el Estatuto de Autonomía de Cataluña (STC 31/2010). Este análisis debe ser el fruto de un contraste individualizado entre los preceptos y el sentido de los fundamentos jurídicos de la sentencia para determinar el alcance del efecto vinculatorio de la misma al resto de los poderes públicos que no han sido parte en la correspondiente sentencia. El propio Tribunal Constitucional es consciente de la problemática al plantear que su doctrina en relación a preceptos similares o

Castellà Andreu, J. M., «La Sentencia del Tribunal Constitucional 31/2010, sobre el Estatuto de Autonomía de Cataluña y su significado para el futuro del Estado Autonómico», op. cit., pág. 10; VINTRÓ Castells, J., «Los dictámenes vinculantes del Consejo de Garantías Estatutarias», Revista Catalana de Dret Públic, $n^{o}$ especial Sentencia sobre el Estatuto, 2010, pág. 1 y ss. De modo crítico con el pronunciamiento, vid. CARRILlo, M., «Después de la sentencia, un Estatuto desactivado», El Cronista del Estado Social y Democrático de Derecho, 2010, octubre, n 15, pág. 36; BALAguer CALlejón, F., «Las cuestiones institucionales en la STC 31/2010, de 28 de junio», El Cronista del Estado Social y Democrático de Derecho, 2010, octubre, nº 15, pág. 68-69. 
idénticos de otros Estatutos de Autonomía tiene efectos ergaomnes y que el recurso de inconstitucionalidad no es el único remedio para depurar el ordenamiento, ya que la potestad de reforma del legislador democrático también es operativa frente a preceptos inconstitucionales $^{86}$. En cualquier caso, dejando al margen este sistema de reparación indirecta a través del legislador ya analizado, nos centraremos en este apartado en los efectos vinculatorios que se pueden plantear para los poderes públicos afectados por otros Estatutos de Autonomía.

En este sentido, los preceptos que han sido objeto de una interpretación conforme a la Constitución producen una vinculación idéntica a la establecida en el correspondiente fundamento, ya que directamente puede desplegar sus efectos en relación a otros preceptos idénticos o similares de otros Estatutos de Autonomía con independencia de que hayan sido impugnados o no, es decir, la vinculación a los fundamentos jurídicos interpretativos afectará tanto a los procesos de producción normativa de desarrollo de dichos Estatutos como a los supuestos de aplicación por parte de órganos judiciales o administrativos, no siendo necesario un nuevo pronunciamiento por parte del Tribunal Constitucional para que se desplieguen los efectos generales y vinculatorios de dicha sentencia a los supuestos similares o idénticos.

La extensión de las sentencias interpretativas a dichos casos es una consecuencia de la misma vinculación a las sentencias del Tribunal Constitucional, y en caso de que se intente realizar una interpretación diferente a la planteada en la jurisprudencia se plantearían unas consecuencias y unos efectos similares a los planteados en comportamientos idénticos a los de las partes en el proceso principal ${ }^{87}$.

La vinculación es objeto de una argumentación diferente, aunque con unas consecuencias similares, en el caso de los preceptos declarados inconstitucionales, nulos y expulsados del ordenamiento jurídico del Estatuto de Autonomía. En este caso también nos encontramos con preceptos similares o idénticos en otros Estatutos de Autonomía, pero no cabe la extensión de los efectos de la declaración de inconstitucionalidad al no poder ser considerados preceptos de la misma ley impugnado, es decir, su nulidad y expulsión requiere un pronunciamiento en un nuevo proceso que necesariamente deberá ser una cuestión de inconstitucionalidad. Ahora bien, los correspondientes fundamentos jurídicos producen un efecto de vinculación a todos los poderes públicos, de forma que su sentido tendrá unos efectos similares a los de una sentencia interpretativa en el caso de que el legislador autonómico deseará desplegar su correspondiente desarrollo normativo. En caso contrario, es decir, si se optara por desarrollar normativamente los preceptos que incurren en la inconstitucionalidad no declarada, se podrá impugnar dicha decisión legislativa mediante el correspondiente recurso de inconstitucionalidad o una eventual cuestión de inconstitucionalidad. En todo caso, si se optara por la solución de la no aplicación hay que recordar que las leyes que no se aplican carecen de consecuencias, por lo que serían equivalentes a un reconocimiento de inconstitucionalidad por los poderes pú-

86 STC 31/2010 FJ 2. Vid sobre el particular Ferreres Comella, V., «El impacto de la Sentencia sobre otros Estatutos», Revista Catalana de Dret Públic, no especial Sentencia sobre el Estatuto, 2010, pág. 1 y ss.

87 En sentido contrario a la extensión de las sentencias interpretativas a otros preceptos estatutarios similares o idénticos, pero planteando la hipótesis contraria, vid. Ferreres Comella, V., «El impacto de la Sentencia sobre otros Estatutos», op. cit., pág. 2-3 
blicos autonómicos sin nulidad, adquiriendo una similar efectividad que el cumplimiento de la STC 31/2010.

En los procesos de aplicación por parte de órganos judiciales se van a generar los mismos efectos que si fuera una sentencia interpretativa, es decir, los órganos judiciales se encuentran vinculados en su interpretación a las correspondientes declaraciones de inconstitucionalidad en preceptos idénticos o similares, pero además el órgano judicial podrá plantear la correspondiente cuestión de inconstitucionalidad tanto en relación a los preceptos de los Estatutos de Autonomía susceptibles de ser aplicados directa o indirectamente al proceso concreto, como a la normativa de desarrollo de los mismos. En todo caso se debe resaltar que siempre se adopta como referente y precedente a la STC 31/2010 en aplicación de preceptos estatutarios idénticos o similares de otras Comunidades Autónomas.

\subsection{LA INCIDENCIA DE LA STC 31/2010 EN LOS PRECEPTOS ESTATUTARIOS Relativos al Poder Judicial}

El primer bloque de preceptos hace referencia al Poder Judicial que con carácter general ha implicado adoptar declaraciones de inconstitucionalidad para atribuir la competencia al Estado, por lo que con carácter interpretativo y vinculatorio debe tener consecuencias para el resto de los poderes públicos autonómicos y para la interpretación de los preceptos idénticos o similares de los respectivos Estatutos.

En relación al Tribunal Superior de Justicia se ha realizado la interpretación conforme del art. 95.2 EAC, en la que el Tribunal Constitucional considera que ha de interpretarse en el sentido de que con la «unificación de doctrina» no se puede definir por el Estatuto la función jurisdiccional del Tribunal Supremo, ni se limita la configuración de la misma por la Ley Orgánica del Poder Judicial, ni se hace referencia a un recurso procesal específico, sino sólo a aquella función reservada al Tribunal Supremo y referida en el Estatuto por relación a su resultado (la unificación de la aplicación e interpretación del Derecho), alcanzado mediante un orden de recursos procesales que sólo a la Ley Orgánica del Poder Judicial corresponde establecer ${ }^{88}$. Los preceptos similares de otros Estatutos de Autonomía (art. 140.2 EAAnd y art. 63.1 EAAra) no hacen referencias a la unificación de doctrina entre las competencias del Tribunal Supremo, ni tampoco condicionan en ningún extremo dichas competencias, por lo que dicha doctrina interpretativa carecerá de consecuencias en relación a dichos preceptos.

Por otra parte, el Tribunal Constitucional consideró inconstitucionales y nulos de forma parcial los art. 95.5 y 6 EAC en la medida en que prevén la participación del Consejo de Justicia de Cataluña en el proceso de propuesta de determinados nombramientos judiciales debido a que ningún órgano, salvo el Consejo General del Poder Judicial, puede ejercer funciones de gobierno de los órganos jurisdiccionales integrados en el Poder

88 STC 31/2010 FJ 44. En general sobre el poder judicial como exclusivo del Estado, vid. ELías MÉNDEZ, C., op. cit., pág. 5. Crítico con la sentencia por su escaso alcance, BLANCO VALDÉs, R. L., op. cit., pág. 14. En contra de los criterios de la STC 31/2010, vid. Aparicio Pérez, M. A., «Comentario a la STC 31/2010. Sobre el Poder Judicial», Revista Catalana de Dret Públic, no especial Sentencia sobre el Estatuto, 2010, pág. 1 y ss. 
Judicial, exclusivo del Estado ${ }^{89}$. En este caso concreto, el art. 143.1 y 2 EAAnd ha previsto la idéntica participación del Consejo de Justicia de Andalucía, por lo que de forma interpretativa y vinculatoria son extendibles los efectos de la doctrina del Tribunal Constitucional a dichos preceptos.

Necesariamente, esta declaración de inconstitucionalidad se debe conectar a la declaración de inconstitucionalidad y nulidad del art. 97 EAC que establecía el Consejo de Justicia de Cataluña, así como de los preceptos atributivos de competencias y reguladores de la composición y funcionamiento del mismo. El Tribunal Constitucional considera que se incurre en un evidente exceso al crear un Consejo de Justicia de Cataluña al que se califica como «órgano de gobierno del poder judicial en Cataluña» y cuyos actos lo serían de un «órgano desconcentrado del Consejo General del Poder Judicial», siendo así que el Poder Judicial (cuya organización y funcionamiento están basados en el principio de unidad ex art. 117.5 CE) no puede tener más órgano de gobierno que el Consejo General del Poder Judicial, cuyo estatuto y funciones quedan expresamente reservados al legislador orgánico (art. 122.2 CE), por lo que se produce una infracción de los arts. 122.2 CE y 149.1.5 $\mathrm{CE}^{90}$. En relación a este precepto existen normas casi idénticas en el art. 144.1 EAAnd y similar en el art. 64 EAAra, pero con notables diferencias que implican que no se haya incurrido en la inconstitucionalidad, ya que en el caso del Estatuto de Andalucía no se hace referencia a que se trate de un órgano desconcentrado y ni siquiera es órgano de gobierno del Poder Judicial, sino de la Administración de Justicia, mientras que en el caso de Aragón se deriva directamente la fijación de los aspectos relativos a la naturaleza de dicho órgano a la Ley Orgánica del Poder Judicial por lo que no existen referencias al hecho de que se trate de un órgano de gobierno y desconcentrado del Poder Judicial. En consecuencia, ninguno de los dos Estatutos incurre en la inconstitucionalidad planteada en este supuesto concreto.

En relación a las atribuciones del Consejo de Justicia previstas en el art. 98.2 EAC, el Tribunal Constitucional considera que incurren en clara inconstitucionalidad y son nulas por tratarse de atribuciones típicas de un órgano de gobierno del Poder Judicial, las contempladas en los apartados a) [participación en la designación de presidentes de órganos judiciales], b) [expedición de nombramientos y ceses de Jueces y Magistrados temporales], c) [funciones disciplinarias sobre Jueces y Magistrados], d) [inspección de Tribunales] y e) [información sobre recursos de alzada contra acuerdos de los órganos de gobierno de los Tribunales y Juzgados de Cataluña], que afectan, sin duda, a la función jurisdiccional propiamente dicha y a la ordenación de los elementos consustanciales a la determinación de la garantía de la independencia en su ejercicio ${ }^{91}$. El art.98.3 EAC, a pesar de no haber sido impugnado, es declarado inconstitucional y nulo por conexión con el art. 97, en cuanto parte de la posibilidad de que el Consejo de Justicia dicte resoluciones en materia de nombramientos, autorizaciones, licencias y permisos de Jueces y Magistrados, funciones que no le corresponden al no admitir como constitucional su conside-

89 STC 31/2010 FJ 45 y 47

90 STC 31/2010 FJ 47. Sobre el particular, vid. CASTELlÀ Andreu, J. M., «La Sentencia del Tribunal Constitucional 31/2010, sobre el Estatuto de Autonomía de Cataluña y su significado para el futuro del Estado Autonómico», op. cit., pág. 16.

91 STC 31/2010 FJ 48 
ración como «órgano de gobierno del poder judicial» ${ }^{92}$. Estos preceptos se regulan de forma casi idéntica en los art. 144.4.a, b, c, d y e EAAnd, así como en el art. 144.5 EAAnd, por lo que de forma interpretativa y vinculatoria son extendibles los efectos de la doctrina del Tribunal Constitucional a dichos preceptos.

El art. 99.1 EAC es considerado inconstitucional y nulo el inciso en relación con el Presidente del Tribunal Superior de Justicia, al atribuirle la presidencia del Consejo de Justicia de Cataluña., ya que la integración de Jueces y Magistrados en su composición supondría hacer uso de la excepción contemplada en el art. 117.4 CE, que impide, por principio, que los Jueces ejerzan funciones ajenas a la potestad jurisdiccional, sin que pueda ser el Estatuto la norma competente para establecer esa excepción ${ }^{93}$. En cuanto al resto de los componentes de este órgano, el precepto estatutario dispone que estará integrado por «los miembros que se nombren, de acuerdo con lo previsto por la Ley Orgánica del Poder Judicial, entre Jueces, Magistrados, Fiscales o juristas de reconocido prestigio». En virtud de esta remisión a la Ley Orgánica del Poder Judicial, es al legislador estatal orgánico al que con plena libertad le corresponde determinar entre qué profesionales de los mencionados en el precepto pueden ser nombrados los componentes del Consejo de Justicia y, en su caso, incluir entre ellos a Jueces y Magistrados, habilitándolos, de esta forma, para el ejercicio de funciones ajenas a la potestad jurisdiccional, debiendo, por lo tanto, desestimarse en este concreto extremo la impugnación de los recurrentes $^{94}$. Un precepto idéntico al planteado se establece en el art. 144.2 EAAnd, por lo que de forma interpretativa y vinculatoria son extendibles los efectos de la doctrina del Tribunal Constitucional a dichos preceptos. Sin embargo, el art. 64.2 EAAr no incurre en la inconstitucionalidad al realizar una simple previsión sin concretar ningún aspecto remitiéndose directamente a la Ley Orgánica del Poder Judicial.

Finalmente en materia de Poder Judicial, se debe tener en cuenta la declaración de inconstitucionalidad y nulidad de los art. 101.1 y 2 EAC en materia de oposiciones y concursos, por cuanto el Consejo de Justicia de Cataluña figura entre las instituciones a las que cabe proponer la convocatoria de oposiciones y concursos para cubrir las plazas vacantes de Magistrados, Jueces y Fiscales en Cataluña, de forma que el Tribunal Constitucional declara inconstitucional y nulo el inciso «o al Consejo de Justicia de Cataluña» como consecuencia de que no puede realizar funciones de órgano de gobierno del Poder Judicial, razonamiento que se extiende a la inconstitucionalidad del apartado 2 del art. $101 \mathrm{EAC}$, en el que se prescribe que el Consejo de Justicia «convoca los concursos para cubrir plazas vacantes de Jueces y Magistrados en Cataluña en los términos establecidos en la Ley Orgánica del Poder Judicial» ${ }^{95}$. Este precepto se regula de forma idéntica en el art. 146 EAAnd, por lo que de forma interpretativa y vinculatoria son extendibles los efectos de la doctrina del Tribunal Constitucional a dicho precepto. 


\subsection{LA ESCASA INCIDENCIA DE LA DOCTRINA CONSTITUCIONAL EN MATERIA DE BLINDAJE COMPETENCIAL}

El segundo bloque de preceptos similares en otros Estatutos de Autonomía hace referencia al denominado blindaje competencial, es decir, un conjunto de reglas para determinar normativamente el significado de los distintos tipos de competencias $^{96}$. El carácter interpretativo de este tipo de normas incide en las competencias interpretativas del propio Tribunal Constitucional, ya que condiciona el significado de normas constitucionales. En todo caso, los efectos de una declaración de inconstitucionalidad de los correspondientes preceptos estatutarios o una declaración de interpretación conforme a la Constitución carece de efectos directos sobre el ordenamiento o la normativa autonómi$\mathrm{Ca}^{97}$, ya que la finalidad de dicha normativa es sobre todo de carácter interpretativo. No obstante, nos encontramos con preceptos que son similares o idénticos en otros Estatutos de Autonomía por lo que se debe proceder al análisis de sus consecuencias.

En relación con las competencias exclusivas, el Tribunal Constitucional considera necesaria una interpretación conforme a la Constitución en el sentido de que el art. 110 EAC no es contrario a la Constitución en tanto que aplicable a supuestos de competencia material plena de la Comunidad Autónoma y en cuanto no impide el ejercicio de las competencias exclusivas del Estado ex art. 149.1 CE, cualquiera que sea la utilización de los términos «competencia exclusiva» o «competencias exclusivas» en los restantes preceptos del Estatuto, sin que tampoco la expresión «en todo caso», reiterada en el Estatuto respecto de ámbitos competenciales autonómicos, tenga otra virtualidad que la meramente descriptiva ni impida, por sí sola, el pleno y efectivo ejercicio de las competencias estatales $^{98}$. Los art. 42.2.1 ${ }^{\circ}$ EAAnd y art. 71 EAAra recogen unos preceptos similares,

96 Sobre el blindaje competencial, CASTEllà Andreu, J. M., «La Sentencia del Tribunal Constitucional 31/2010, sobre el Estatuto de Autonomía de Cataluña y su significado para el futuro del Estado Autonómico», op. cit., pág. 12-13; Elías MéndeZ, C., op. cit., pág. 26 y ss.; BlanCo ValdéS, R. L., op. cit., pág. 14-16; CaRRILlO, M., «Después de la sentencia, un Estatuto desactivado», op. cit., pág. 29-31; García Roca, J., op. cit., pág. 57-59; Fernández Farreres, G., «Las competencias de Cataluña tras la Sentencia del Tribunal Constitucional sobre el Estatut», El Cronista del Estado Social y Democrático de Derecho, 2010, octubre, nº 15, pág. 4447; De la Quadra-Salcedo Janini, T., «El modelo competencial en la STC 31/2010, de 28 de junio», El Cronista del Estado Social y Democrático de Derecho, 2010, octubre, $\mathrm{n}^{\circ}$ 15, pág. 72-75. Sobre la definición estatutaria de las competencias, vid. BARCELÓ i Serramalera, M., «La doctrina de la STC 31/2010 sobre la definición estatutaria de las categorías competenciales», Revista Catalana de Dret Públic, $n^{o}$ especial Sentencia sobre el Estatuto, 2010, pág. 1 y ss.; CARrillo, M., «La doctrina del Tribunal sobre la definición de las competencias. Las competencias exclusivas, las compartidas y las ejecutivas», Revista Catalana de Dret Públic, $n^{\circ}$ especial Sentencia sobre el Estatuto, 2010, pág. 1 y ss.; Corretja Torrens, M., «Los efectos de la sentencia sobre la definición estatutaria de las competencias: la «devaluación» jurídica de los Estatutos de Autonomía», Revista Catalana de Dret Públic, $n^{\circ}$ especial Sentencia sobre el Estatuto, 2010, pág. 1 y ss.

97 Califica de sentencia interpretativa de rechazo los argumentos en materia de blindaje competencial García Roca, J., op. cit., pág. 52-53.

98 TC 31/2010 FJ 59. La atribuci por el Estatuto a la Generalitat de competencias exclusivas sobre una materia en los t minos del art. 110 EAC no puede afectar a las competencias reservadas al Estado, que se proyectar, cuando corresponda, sobre dichas competencias exclusivas auton icas con el alcance que les haya otorgado el legislador estatal con plena libertad de configuraci, sin necesidad de que el Estatuto incluya cl sulas de salvaguardia de las competencias estatales (FJ 64). En cuanto a la t nica seguida en ocasiones por el Estatuto de atribuir competencias materiales a la Generalitat que se proyectan n todo caso sobre las submaterias correspondientes, la Sentencia reitera que dicha expresi ha de entenderse en sentido meramente descriptivo o 
pero en los mismos se hace mención específica de la salvaguarda de las competencias exclusivas del Estado, mencionando de forma directa el art. 149.1.1 CE, de modo que no es necesario extender los efectos vinculatorios del pronunciamiento del Tribunal Constitucional.

Sobre las competencias compartidas, el Tribunal Constitucional considera inconstitucional y nulo parcialmente el art. $111 \mathrm{EAC}$ al describir el supuesto de concurrencia de competencias de acuerdo con el criterio bases/desarrollo pero no se atiene estrictamente al concepto constitucional de las bases estatales porque las reduce a los «principios o mínimo común normativo» fijados por el Estado «en normas con rango de ley», cuando es posible predicar el carácter básico de normas reglamentarias y de actos de ejecución del Estado y las bases pueden tener un alcance diferente dependiendo de la materia. En consecuencia, es inconstitucional y nulo el inciso «como principios o mínimo común normativo en normas con rango de ley, excepto en los supuestos que se determinen de acuerdo con la Constitución y el presente Estatuto». Con su supresión, el art. 111 EAC se limita a describir correctamente las facultades comprendidas en la competencia de desarrollo de unas bases estatales cuyo contenido y alcance serán siempre, y sólo, las que se desprenden de la Constitución interpretada por este Tribunal ${ }^{99}$. También en este caso nos encontramos con preceptos de otros Estatutos similares al precepto recurrido como son el art. 42.2.2 EAAnd y el art. 75 EAAra, pero completamente diferentes ya que no se hace mención al inciso declarado inconstitucional, es decir, no califica las bases estatales como principios o mínimo común normativo en normas con rango de ley, por lo que tampoco es necesario extender los efectos vinculatorios de la sentencia a dichos Estatutos.

Finalmente, en relación con las competencias ejecutivas, el Tribunal Constitucional adopta una interpretación conforme a la Constitución para determinar que la competencia ejecutiva de la Generalitat puede ejercerse, a partir de «la normativa (legal y reglamentaria) del Estado», sólo como función ejecutiva stricto sensu y no como potestad reglamentaria de alcance general, de modo que sólo entendida la potestad reglamentaria a que se refiere el art. 112 EAC, limitada a la emanación de reglamentos de organización interna y de ordenación funcional de la competencia ejecutiva autonómica, no perjudica a la constitucionalidad del art. $112 \mathrm{EAC}^{100}$. En este caso también nos encontramos con supuestos similares en los art. 42.2.3 ${ }^{\circ}$ EAAnd y art. 77 EAAra, pero que no incurren en

indicativo de que dichas submaterias forman parte del contenido de la realidad material de que se trate, pero sin que las competencias del Estado, tanto si son concurrentes como si son compartidas con las de la Comunidad Aut oma, resulten impedidas o limitadas en su ejercicio por esa atribuci estatutaria n todo caso de competencias espec icas a la Generalitat. te es el sentido en que habr de ser entendida dicha expresi que figura en determinados preceptos impugnados (arts. $117.1 ; 118.1$ y $2 ; 120.1,2$ y $3 ; 121.1$ y $2 ; 123 ; 125.1$ y $4 ; 127.1$ y $2 ; 131.3 ; 132.1 ; 133.1$ у $4 ; 135.1 ; 139.1 ; 140.5$ у $7 ; 147.1 ; 149.3 ; 151 ; 152.4 ; 154.2 ; 155.1 ; 166.1,2$ y 3 ; 170.1 y $172.2 \mathrm{EAC})$

99 STC 31/2010 FJ 60. La atribución estatutaria de competencias a la Generalitat compartidas con el Estado según el criterio bases/desarrollo (art. 111 EAC) no impedirá que las bases estatales configuren con plena libertad las distintas materias y submaterias de un mismo sector material, de suerte que cuando así sea la exclusividad respecto de tales materias y submaterias eventualmente proclamada por el Estatuto lo será impropiamente, sin cercenar ni menoscabar la proyección de la competencia exclusiva estatal sobre las bases de dichas materias o submaterias (FJ 64)

100 STC 31/2010 FJ 61 
la inconstitucionalidad, ya que se introducen salvedades para indicar que cuando proceda se ejercerá la potestad reglamentaria o se limita esta potestad directamente a los ámbitos acordes con la jurisprudencia clásica del Tribunal Constitucional en estos ámbitos.

En resumen en este bloque a pesar de encontrarnos con preceptos similares en otros Estatutos de Autonomía, estos no se ven condicionados por la jurisprudencia del Tribunal Constitucional, ya que no incurren en las causas de inconstitucionalidad o en las interpretaciones conformes a la Constitución establecidas en relación a los preceptos estatutarios sobre el blindaje competencial que en esencia no aparecían recogidos en otros Estatutos de Autonomía.

\subsection{LA INEXISTENCIA DE CONSECUENCIAS DIRECTAS PARA OTROS PRECEPTOS ESTATUTARIOS DE LA STC 31/2010 EN MATERIA DE COMPETENCIAS ESPECÍFICAS}

El tercer bloque hace referencia a pronunciamientos del Tribunal Constitucional sobre competencias específicas en las que nos encontramos preceptos similares o idénticos en otros Estatutos de Autonomía. Este bloque se caracteriza por la heterogeneidad temática y material, pero también porque frecuentemente se aplica principios generales de la jurisprudencia constitucional sobre el blindaje competencial a casos concretos, por lo que específicamente no se aporta conclusiones diferentes a las analizadas en el apartado anterior.

En primer lugar, en materia de cajas de ahorro, se considera nulo e inconstitucional el art. 120.2 EAC, ya que dicho precepto formaliza la competencia autonómica como «competencia compartida» que, de acuerdo con el enjuiciamiento del art. $111 \mathrm{EAC}$, significa que este tipo de competencia se configura y ejerce «en el marco de las bases que dicte el Estado». Ahora bien, respecto a la configuración que el precepto hace de las bases estatales como "principios, reglas y estándares mínimos», al definir la competencia autonómica el Estatuto no puede determinar el modo de ejercicio ni el alcance de las competencias exclusivas del Estado ${ }^{101}$. Este precepto fundamentalmente tiene carácter interpretativo, de forma que un precepto idéntico, es decir, el art. 75.2 EAAnd debe considerarse condicionado y vinculado por la jurisprudencia, pero insistiendo en la idea de que se trata de una declaración de inconstitucionalidad y nulidad con efectos principalmente interpretativos para salvaguardar las competencias del Estado y su alcance no tiene repercusiones en el correspondiente ordenamiento autonómico al margen de que se produzca una invasión de competencias estatales.

En relación con las consultas populares, el Tribunal Constitucional consideró que la competencia prevista en el art. 122 EAC es perfectamente conforme con la Constitución, en el bien entendido de que en la expresión «cualquier otro instrumento de consulta popular» no se comprende el referéndum ${ }^{102}$. El art. 78 EAAnd recoge un precepto similar, pero de forma expresa se excluye el referéndum, de modo que el criterio interpretativo

101 STC 31/2010 FJ 67

102 STC 31/2010 FJ 69 
del Tribunal Constitucional carece de relevancia en relación al mencionado precepto estatutario.

En materia de crédito, banca, seguros y mutualidades no integradas en el sistema de seguridad social, el Tribunal Constitucional considera de nuevo que la fijación por el art. 126.2 EAC de la forma de ejercicio por el Estado de sus competencias sobre la legislación básica no respeta la Constitución, es decir, el inciso «los principios, reglas y estándares mínimos fijados en» es inconstitucional y nulo ${ }^{103}$. El art. 75.7 EAAnd es similar, pero el inciso declarado inconstitucional no aparece en su tenor literal por lo que el pronunciamiento carece de relevancia en la interpretación de dicho precepto estatutario.

En relación con la materia de cultura, el Tribunal Constitucional establece una interpretación conforme a la Constitución respecto a la primera de las previsiones del art. 127.3 EAC, es decir, a la necesidad del acuerdo previo de la Generalidad para realizar el Estado inversiones en bienes y equipamientos culturales. El art. 149.2 CE impone también al Estado que el cumplimiento de sus responsabilidades en el ámbito de la cultura se verifique «de acuerdo con ellas», lo que implica antes una invocación genérica y de principio a la colaboración entre Administraciones que son titulares de competencias concurrentes en un ámbito material compartido, en el que el sometimiento del ejercicio de las competencias del Estado a la condición del consentimiento de las Comunidades Autónomas en cada caso sería incompatible con su naturaleza indisponible e irrenunciable $^{104}$. El art. 68.5 EAAnd es similar al precepto estatutario catalán, pero no somete a la condición de consentimiento previo las inversiones estatales, sino que prevé una participación de la Comunidad Autónoma que es compatible con el criterio interpretativo del Tribunal Constitucional.

Como se puede deducir con facilidad en este tercer bloque dedicado a las competencias específicas tampoco se produce unas consecuencias excesivamente diferentes a las anteriores, ya que la jurisprudencia del Tribunal Constitucional no ha a dar lugar a consecuencias directas en los preceptos de los otros Estatutos de Autonomía, o en todo caso solo los va a condicionar interpretativamente para respetar las competencias del Estado.

\subsection{LA INCIDENCIA INTERPRETATIVA DE LA STC 31/2010 EN MATERIA DE RELACIONES INSTITUCIONALES DE CARÁCTER BILATERAL Y DE REFORMA DEL ESTATUTO}

Este bloque hace referencia a las relaciones institucionales entre el Estado y la Comunidad Autónoma basadas esencialmente en la bilateralidad, en las que fundamentalmente se trata de proteger frente a la condicionabilidad de las decisiones del Estado en el marco de sus competencias, de forma que cualquier organismo o institución basado en la bilateralidad de las relaciones no puede condicionar ser excluyente de las obligaciones constitucionales basadas en la multilateralidad propia de un federalismo cooperativo en el que se fundamenta las referidas relaciones institucionales en nuestro sistema autonómico ${ }^{105}$.

103 STC 31/2010 FJ 72

104 STC 31/2010 FJ 73

105 Sobre la bilateralidad como modo de relación en la STC 31/2010, vid. ELí́As MÉNDEZ, C., op. cit., pág. 
En este sentido, en relación con la participación de la Generalidad en la toma de decisiones estatales, el Tribunal Constitucional estableció una interpretación conforme a la Constitución del art. 174.3 EAC, que ha de interpretarse en el sentido de que prevé una participación orgánica y procedimental de la Generalidad que habrá de ser regulada por la legislación estatal y que no puede sustanciarse respecto de los órganos decisorios del Estado ni impedir o menoscabar el libre y pleno ejercicio de las competencias estatales ${ }^{106}$. Este criterio interpretativo es plenamente aplicable al art. 89.1 EAAra que establece en términos casi idénticos una disposición semejante, que se encontrará en su interpretación vinculada por el pronunciamiento del Tribunal Constitucional.

En relación con la Comisión Bilateral Generalitat-Estado, el Tribunal Constitucional considera que la calificación que el art. 183.1 EAC efectúa de dicha Comisión Bilateral como «marco general y permanente de relación entre los Gobiernos de la Generalitat» y del Estado, no es contraria a la Constitución interpretada en el sentido de que no excluye otros marcos de relación, ni otorga a dicha Comisión función distinta de la de cooperación voluntaria en el ámbito de las competencias de ambos Gobiernos, que son indisponibles, es decir, no vulnera la Constitución si no impide ni menoscaba el libre y pleno ejercicio por el Estado de sus propias competencias ${ }^{107}$. Este criterio interpretativo es aplicable en el caso del art. 220 EAAnd y del art. 90 EAAra, que pueden considerarse preceptos casi idénticos o similares, siendo vinculados y condicionados por el pronunciamiento del Tribunal Constitucional.

Como se puede deducir en este ámbito las repercusiones en los preceptos estatutarios de otras Comunidades Autónomas son de carácter interpretativo por lo que la vinculación al pronunciamiento del Tribunal Constitucional es plena en ambos supuestos.

Otro bloque de preceptos similares en otros Estatutos de Autonomía con incidencia meramente interpretativa hace referencia a las normas en materia de reforma del Estatuto. En este supuesto el Tribunal Constitucional ha sometido a una interpretación conforme a la Constitución a los contenidos del art. 222.1.d y del art. 223.1.i EAC, que no son inconstitucionales siempre que se interpreten entendiendo que la referencia a la autorización y convocatoria del referéndum en el art. 223 EAC es también el aplicable al art. 222 $\mathrm{EAC}$, de forma que aunque dicho régimen parte de la premisa de que el referéndum de ratificación debe ser autorizado por el Estado, observando el respeto debido al art. 149.1.32 $2^{\mathrm{a}} \mathrm{CE}$, no se fija si la autorización estatal debe dispensarla el Gobierno o las Cortes Generales ${ }^{108}$, considerando el Tribunal Constitucional ante el silencio del art. 152.2 CE y las excepciones contenidas en la Ley Orgánica 2/1980, de 18 de enero, que permiten para determinados supuestos la reserva al Congreso de los Diputados de la autorización de determinados referenda, que en el presente caso la reserva se hace extensiva a las

13. Sobre el alcance de las relaciones institucionales basadas en la bilateralidad, vid. PARIS, N., «Las relaciones institucionales de la Generalitat en la Sentencia sobre el EAC», Revista Catalana de Dret Públic, $n^{\circ}$ especial Sentencia sobre el Estatuto, 2010, pág. 1 y ss. y Pérez Velasco, M. M., "Comentario de la Sentencia del Tribunal Constitucional que resuelve el recurso de inconstitucionalidad presentado por el PP contra el Estatuto de Autonomía de Cataluña: Comisión Bilateral Generalitat-Estado (artículo 183 EAC)», Revista Catalana de Dret Públic, $n^{\circ}$ especial Sentencia sobre el Estatuto, 2010, pág. 1 y ss.

106 STC 31/2010 FJ 111

107 STC 31/2010 FJ 115

108 STC 31/2010 FJ 144 
dos Cámaras de las Cortes Generales ${ }^{109}$. En este supuesto existen preceptos similares en el art. 248.3 EAAnd y en el art. 115.7 EAAra, que se verán condicionados por esta interpretación conforme a la Constitución, ya que se trata de fijar un criterio interpretativo para evitar en el futuro inseguridades jurídicas, que al mismos tiempo trata de respetar las atribuciones competenciales estatales y las decisiones de los correspondientes órganos constitucionales.

\subsection{LA INCIDENCIA DE LA STC 31/2010 EN MATERIA DE FINANCIACIÓN AUTONÓMICA}

El siguiente bloque temático hace referencia a los preceptos similares o idénticos de otros Estatutos en materia de financiación autonómica. En este caso, nos volvemos a encontrar con preceptos sometidos a una interpretación conforme a la Constitución que son plenamente vinculantes en casos similares o en caso de declaración de inconstitucionalidad o nulidad la finalidad es atribuir la competencia al Estado o no condicionar el ejercicio de las mismas, con lo que carece de efectos directos en el ordenamiento autonómico, de forma que son plenamente aplicables y vinculantes como criterio interpretativo de los mencionados preceptos estatutarios ${ }^{110}$.

En primer lugar, se analizan los mecanismos de nivelación y solidaridad previstos en el art. 206.3 EAC, respecto al cual el Tribunal Constitucional considera que el inciso «siempre y cuando lleven a cabo un esfuerzo fiscal también similar» incurre en inconstitucionalidad. Aunque el precepto no concreta cuál haya de ser el contenido y alcance que tenga la expresión «esfuerzo fiscal», establece como exigencia para que Cataluña contribuya a los mecanismos de nivelación de servicios fundamentales y de solidaridad el que las restantes Comunidades Autónomas realicen un «esfuerzo fiscal similar» al que haga Cataluña, prescripción ésta que es determinante de la inconstitucionalidad señalada, ya que al Estado le corresponde, ex art. 149.1.14 CE en su conexión con los arts. 138.1 y 157.3 CE, regular el ejercicio de las competencias financieras de las Comunidades Autónomas y fijar los niveles de su contribución a la nivelación y a la solidaridad, lo que reconoce el propio art. 206.3, último inciso, del Estatuto. En este contexto, la determinación de cuál sea el esfuerzo fiscal que hayan de realizar las Comunidades Autónomas es cuestión que sólo corresponde regular al propio Estado, tras las actuaciones correspondientes en el seno del sistema multilateral de cooperación y coordinación constitucionalmente previsto ${ }^{111}$. En este supuesto, los preceptos similares al impugnado con un contenido casi idéntico se encuentran en los art. 175.2.c EAAnd, art. 123.2 EABal y art.

109 STC 31/2010 FJ 145

110 Sobre el alcance de la STC 31/2010 en materia de financiación autonómica, vid. Alonso GonZÁLEZ, L. M., «La financiación de la Generalitat (STC 31/2010, de 28 de junio)», Revista Catalana de Dret Públic, $n^{0}$ especial Sentencia sobre el Estatuto, 2010, pág. 1 y ss.; Arias Abellán, M. D., «Sobre la constitucionalidad de determinados preceptos del Estatuto de Autonomía de Catalunya relativos a la financiación autonómica y local», Revista Catalana de Dret Públic, $n^{\circ}$ especial Sentencia sobre el Estatuto, 2010, pág. 1 y ss.; PAGÈs I GALTÉs, J., «La financiación autonómica en la Sentencia 31/2010 del Tribunal Constitucional sobre el Estatuto catalán de 2006», Revista Catalana de Dret Públic, $n^{0}$ especial Sentencia sobre el Estatuto, 2010, pág. 1 y ss.

111 STC 31/2010 FJ 134 
107.2 EAAra, lo que supone que se sitúan en la vinculación como criterio interpretativo de los mismos a la doctrina del Tribunal Constitucional sobre dicho extremo. Por lo demás se debe recordar que la consecuencia de la inconstitucionalidad es la atribución de la competencia al Estado por lo que dichos preceptos no tienen consecuencias en los ordenamientos autonómicos respectivos desde un punto de vista interno, salvo que se intente producir una invasión directa de las competencias estatales.

Por otra parte, en relación al art. 206.5 EAC se ha establecido una interpretación conforme a la Constitución en el sentido de que debe de entenderse como la manifestación expresa de un principio inherente al modelo de solidaridad interterritorial, en cuya virtud el Estado viene constitucionalmente obligado a procurar un «equilibrio económico, adecuado y justo» entre las Comunidades Autónomas que no perjudique a las más prósperas más allá de lo razonablemente necesario para el fin de la promoción de las menos favorecidas. De modo que la garantía del Estado a que se refiere este precepto sólo operaría cuando la alteración de la posición de la Comunidad Autónoma de Cataluña se debiera, no a la aplicación general de los mecanismos de nivelación, sino exclusivamente a la aportación que realizase Cataluña como consecuencia de su posible participación en dichos mecanismos ${ }^{112}$. Un precepto similar se encuentra en el art. 123.3 EABal, pero en el sentido marcado por la interpretación del Tribunal Constitucional por lo que no se verá condicionado, ni vinculado por el pronunciamiento concreto.

En relación con la Comisión Mixta de Asuntos Económicos y Fiscales Estado-Generalitat, el Tribunal Constitucional considera que el art. 210.1 EAC, que formaliza en el Estatuto la existencia de la Comisión Mixta de Asuntos Económicos y Financieros como órgano bilateral de cooperación entre el Estado y la Generalitat en «el ámbito de la financiación autonómica», no resulta inconstitucional siempre que se interprete en el sentido de que no excluye ni limita la capacidad de los mecanismos multilaterales en materia de financiación autonómica ni quebranta la reserva de ley orgánica prevista en el art. 157.3 CE y las consiguientes competencias estatales. Por otra parte, la determinación del alcance y condiciones de la cesión de tributos y los porcentajes de participación en el rendimiento de los tributos cedidos parcialmente a la Generalitat [letra a) del art. 210.2 EAC], la contribución de la Generalitat a la solidaridad y a la nivelación de servicios públicos fundamentales [letra b)] y el porcentaje de participación de Cataluña en la distribución territorial de los fondos estructurales europeos [letra d)] son aspectos, todos ellos, que guardan directa conexión con lo establecido en los arts. 157.1 y 3 y $158 \mathrm{CE}$, debiendo ser regulados por el Estado con referencia al marco específico de coordinación y colaboración entre aquél y las Comunidades Autónomas que la Constitución ha previsto, por tratarse de cuestiones que afectan a todas las Comunidades Autónomas. En definitiva, en el art. 210 EAC las funciones de cooperación de la Comisión Mixta de Asuntos Económicos y Fiscales Estado-Generalitat no excluyen ni limitan la capacidad de las instituciones y organismos de carácter multilateral en materia de financiación autonómica, no afectan a la reserva de Ley Orgánica prevista en el art. 157.3 CE, ni sustituyen, impiden o menoscaban el libre y pleno ejercicio por el Estado de sus propias competencias $^{113}$. Como se puede deducir con facilidad, nos encontramos ante una 
interpretación conforme a la Constitución, que determina la atribución de la competencia al Estado, por lo que puede producir plenos efectos vinculatorios en relación a preceptos similares o idénticos de otros Estatutos de Autonomía. En este sentido, el art. 210.1 EAC es casi idéntico al art. 184.1 EAAnd y similar al art. 109.1 EAAra, mientras que el art. 210.2.a, b y c EAC tienen preceptos comparables en los art. 184.4.a, b y c EAAnd y art. 109.2.a, b y c EAAra, de forma que los criterios interpretativos establecidos por el Tribunal Constitucional pueden desplegar sus efectos vinculatorios en las respectivos preceptos estatutarios.

En relación a la financiación local, el Tribunal Constitucional considera que el art. 218.2 EAC atribuye a la Generalitat una genérica competencia en materia de financiación local que contradice los títulos competenciales del Estado contemplados en los apartados 14 y 18 del art. 149.1 CE. En esencia, se trata de una potestad exclusiva y excluyente del Estado que no permite intervención autonómica en la creación y regulación de los tributos propios de las entidades locales, de forma que al incluir la capacidad legislativa para establecer y regular los tributos propios de los gobiernos locales en el art. 218.2 EAC resulta inconstitucional ${ }^{114}$. En los Estatutos de Autonomía de Andalucía (art. 60.3 y art. 192 EAAnd) y de Aragón (art. 114 EAAra) existen preceptos similares que inciden en las Haciendas Locales, pero que de forma expresa respetan el alcance de las competencias estatales para fijar los criterios de la financiación local, de forma que no incurren en la inconstitucionalidad planteada.

Por último, en materia financiera se debe analizar una serie de disposiciones adicionales sobre cesión de diversos impuestos estatales, que fueron objeto de una interpretación conforme a la Constitución (Disposiciones Adicionales 8, 9 y 10 EAC), para garantizar de que se trataban de especialidades procedimentales que afecta al trámite previo de la iniciativa legislativa, sólo admisible desde el absoluto respeto a la potestad legislativa del Estado que ejercen las Cortes Generales (art. 66.2 CE) y que únicamente puede traducirse en el compromiso de la Generalitat y el Gobierno a acordar en Comisión Mixta — con sujeción a lo dispuesto en el marco de la cooperación multilateral y al ejercicio de las facultades de coordinación que competen al Estado en materia financiera- la elaboración y el contenido de un proyecto de ley ordinaria cuya sustanciación como expresión de la voluntad legislativa depende de la plena libertad de las Cortes Generales ${ }^{115}$. En este caso, nos encontramos con un precepto similar en la Disp. Adic. $4^{a}$ EABal, pero que no condiciona la iniciativa legislativa en materia de cesión de impuestos estatales, de forma que no es necesario aplicar a su interpretación la doctrina del Tribunal Constitucional.

En definitiva, en materia de financiación autonómico tampoco se produce una necesidad de desplegar excesivo efectos vinculatorios a los preceptos de otros Estatutos de Autonomía, salvo para aplicar criterios interpretativos, ya que o bien no son aplicables al caso concreto las declaraciones de inconstitucionalidad o se basan en una garantía de pro-

114 STC 31/2010 FJ 140. Sobre el alcance de la STC 31/2010 en materia de financiación local, vid. Peretó García, M., «Inconstitucionalidad de las competencias relativas a la posibilidad de establecer y regular tributos locales propios», Revista Catalana de Dret Públic, no especial Sentencia sobre el Estatuto, 2010, pág. 1 y ss.

115 STC 31/2010 FJ 137 
tección de las atribuciones del Estado sin excesivas repercusiones para los ordenamientos internos autonómicos.

\subsection{UNA INCIDENCIA INTERPRETATIVA Y MENOR DE LA STC 31/2010 EN LOS PRECEPTOS ESTATUTARIOS DE OTRAS COMUNIDADES AUTÓNOMAS}

El análisis detallado de los preceptos similares o idénticos en los otros Estatutos a los declarados inconstitucionales, nos permite constatar principalmente dos situaciones, o se tratan de preceptos sometidos a una interpretación conforme a la Constitución con plenos efectos vinculatorios para los poderes públicos de la respectiva Comunidad Autónoma por lo que no hay diferencias con los efectos relativos a la Generalidad de Cataluña, o se trata de preceptos declarados inconstitucionales y nulos pero con la consecuencia de reconocer la plena competencia en la materia concreta a favor del Estado, es decir, conlleva de forma implícita una declaración de competencia del Estado o de los correspondientes órganos constitucionales por lo que los efectos no tienen consecuencias directas en el ordenamiento autonómico respectivo, salvo que se adopte decisiones de desarrollo normativo o de aplicación que generarán conflictos de competencia, recursos de inconstitucionalidad o eventuales cuestiones de inconstitucionalidad en caso de incumplimiento a través de una invasión de competencias estatales.

En conclusión, se debe plantear que no era tan relevante el hecho de que no se hubieran impugnado mediante recurso de inconstitucionalidad los preceptos de los Estatutos de Autonomía similares o idénticos al de Cataluña, ya que las coincidencias son susceptibles de ser tratadas a través de criterios interpretativos. La mayoría de los preceptos estatutarios declarados inconstitucionales y nulos por la STC 31/2010 carecen de consecuencias en los otros Estatutos de Autonomía, y cuando se produce una relación de identidad son reconducibles por los efectos vinculatorios de la sentencia del Tribunal Constitucional, sin necesidad de que sea imprescindible la adopción de una nueva decisión de inconstitucionalidad expresa por parte del Tribunal Constitucional. La combinación de criterios interpretativos con declaración de inconstitucionalidad parcial ha implicado desmontar posibles argumentaciones de incoherencias de la STC 31/2010 con los preceptos estatutarios de otras Comunidades Autónomas. Dichas incoherencias solo se podrían plantear en relación a preceptos del Estatuto que de forma global y radical fueron excluidos y expulsados del ordenamiento jurídico, por ejemplo, los dictámenes vinculantes del Consejo de Garantías Estatutarias, pero dicho supuesto no afecta a ninguno de los preceptos de los Estatutos de las otras Comunidades Autónomas.

En cualquier caso, para finalizar hay que destacar que desde un punto de vista sustancial la STC 31/2010 no introduce grandes novedades sobre las líneas jurisprudenciales que había adoptado el Tribunal Constitucional con anterioridad en materia de distribución de competencias o de función constitucional del Estatuto ${ }^{116}$, por lo que en

116 Carreras pienso con razón que la sentencia no es doctrinalmente innovadora, por lo que ha sido un error del legislador democrático ignorar la jurisprudencia del Tribunal Constitucional, intentando establecer unas nuevas bases para el sistema autonómico, vid. CARreras SERra, F. de, « ¿Es constitucional el Estatuto de Cataluña», op. cit., pág. 14. Asimismo, vid. Castellà Andreu, J. M., «La Sentencia del Tribunal Constitu- 
realidad lo único que se ha cuestionado es una innovación estatutaria pensada como un mecanismo de posibilitar la modificación de precedentes del Tribunal Constitucional sin una previa y necesaria reforma constitucional, pero sin dicha reforma los cambios de criterios del Tribunal siempre son difíciles de articular.

\section{CONCLUSIÓN: LOS EFECTOS DE LA STC 31/2010 COMO UNA VINCULACIÓN E INCIDENCIA FUNDAMENTALMENTE INTERPRETATIVA}

La STC 31/2010 se caracteriza por el hecho de que por primera vez se declara la inconstitucionalidad de preceptos estatutarios que mantienen relaciones de jerarquía y de respeto normativo con otros actos y normas de rango legal del propio ordenamiento autonómico. El Estatuto de Autonomía es norma de cabecera de un ordenamiento propio, de forma que la nulidad, así como la interpretación conforme a la Constitución de los preceptos estatutarios implica un mandato que es susceptible de ser examinado como efecto vinculatorio específico de la sentencia del Tribunal Constitucional. En este sentido, es susceptible de generar consecuencias en idénticos mandatos de otras normas legales que mantienen relaciones de dependencia e inferioridad jerárquica con los preceptos declarados inconstitucionales del Estatuto de Autonomía, o incluso de carácter interpretativo con los preceptos similares o idénticos de los Estatutos de otras Comunidades Autónomas.

En este sentido, en relación con las normas legales adoptadas en el pasado para la ejecución de las normas estatutarias declaradas inconstitucionales que no supongan hechos nuevos y existe una relación clara de identidad y casualidad, se pueden considerar vicisitudes anteriores de la misma relación jurídica enjuiciada en la sentencia y responden al mismo mandato declarado inconstitucional. Cualquier hecho nuevo requiere un proceso probatorio y de cognición, en definitiva, un nuevo proceso, pero los mismos hechos o mandatos declarados inconstitucionales, que pertenecen al pasado conocido y que han perdido su fundamentación y base estatutaria, deben quedar enmarcados en el mismo proceso. De este modo, para dichos supuestos sería aplicable en caso de mantenimiento del incumplimiento del mandato jurisprudencial, las prescripciones de ejecución de las sentencias del Tribunal Constitucional, ya que se trata de una derivación del proceso principal.

En consecuencia, si estamos ante un precepto estatutario que ha sido objeto de una interpretación conforme en un determinado fundamento jurídico de la sentencia, el contraste y los efectos se debe realizar de un modo concreto y específico, es decir, siempre se va a requerir un nuevo pronunciamiento para determinar si efectivamente la ley de desarrollo legislativo aprobado por el Parlamento autonómico o por la autoridad autonómica con potestad legislativa incurre en la inconstitucionalidad interpretativa planteada por el Tribunal Constitucional. Este será el supuesto más numeroso de los planteados y no solo porque mayoritariamente la sentencia del Estatuto tiene carácter interpretativo, sino porque también muchas de las declaraciones de inconstitucionalidad más que efectos jurídicos directos sobre el ordenamiento van a tener consecuencias en realidad sobre la normativa estatal, o 
bien la expulsión del ordenamiento del precepto estatutario no condiciona materialmente ningún acto normativo de carácter legal de la Comunidad Autónoma. No es extraño que haya sido considerado que la utilización de sentencias interpretativas ha sido en cierto modo un sistema de cerrar el debate en falso, ya que se requerirá necesariamente un nuevo pronunciamiento sobre la mayoría de la normativa de desarrollo para determinar si se adecua o no a la interpretación conforme fijada por el Tribunal Constitucional.

En definitiva, se debe destacar y concluir que frente a la normativa de desarrollo autonómica del Estatuto si es posterior a la STC 31/2010 necesariamente se debe realizar un nuevo pronunciamiento en materia de control de constitucionalidad. Si está normativa ha sido aprobada con anterioridad a la Sentencia se debe analizar materialmente en el caso concreto, pero en general si afecta a una interpretación conforme a la Constitución necesariamente se debe realizar un nuevo control de constitucionalidad, y lo mismo sucede en el caso de una declaración de inconstitucionalidad y nulidad parcial de un precepto del Estatuto, ya que se requiere realizar un nuevo examen sobre el alcance concreto, siendo la labor interpretativa específica del caso. No obstante, si nos encontramos ante un precepto que en su integridad ha sido declarado inconstitucional y nulo, dada la característica del Estatuto como norma de cabecera y atributiva de la concreta competencia, implica que todos los preceptos subordinados a dicha norma concreta expulsada en su integridad del ordenamiento, incurran en el mismo mandato de inconstitucionalidad, es decir, en su existencia depende de un precepto inexistente con carácter retroactivo, con una sentencia con plenos efectos hacia el pasado y que en todo caso como efecto vinculatorio simplemente debe ser objeto de ejecución.

Como se puede comprobar no es que estemos ante un supuesto que afecte a numerosos preceptos, ya que solamente es hipotéticamente aplicable al caso concreto del art. 18 de la Ley del Consejo de Garantías Estatutarias, ya que en esencia la STC 31/2010 es una sentencia de carácter interpretativo o declarativo de inconstitucionalidad parcial por lo que la extensión de sus efectos a otras normas requiere casi siempre de un nuevo proceso de control de constitucionalidad. Otra cosa distinta es la vinculación de los efectos a los procesos de aplicación en los que el control y la vinculación a los poderes judicial y ejecutivo merecen otra consideración.

Por otra parte, los preceptos que han sido objeto de una interpretación conforme a la Constitución producen una vinculación que directamente puede desplegar sus efectos en relación a otros preceptos idénticos o similares de otros Estatutos de Autonomía con independencia de que hayan sido impugnados o no, es decir, la vinculación a los fundamentos jurídicos interpretativos afectará tanto a los procesos de producción normativa de desarrollo de dichos Estatutos como a los supuestos de aplicación por parte de órganos judiciales o administrativos, no siendo necesario un nuevo pronunciamiento por parte del Tribunal Constitucional para que se desplieguen los efectos generales y vinculatorios de dicha sentencia a los supuestos similares o idénticos.

La vinculación es objeto de una argumentación diferente, aunque con unas consecuencias similares, en el caso de los preceptos declarados inconstitucionales, nulos y expulsados del ordenamiento jurídico del Estatuto de Autonomía. En este caso también nos encontramos con preceptos similares o idénticos en otros Estatutos de Autonomía, pero no cabe la extensión de los efectos de la declaración de inconstitucionalidad al no poder ser considerados preceptos de la misma ley impugnado, es decir, su nulidad y expulsión 
requiere un pronunciamiento en un nuevo proceso que necesariamente deberá ser una cuestión de inconstitucionalidad. Ahora bien, los correspondientes fundamentos jurídicos producen un efecto de vinculación a todos los poderes públicos, de forma que su sentido tendrá unos efectos similares a los de una sentencia interpretativa en el caso de que el legislador autonómico deseará desplegar su correspondiente desarrollo normativo. En caso contrario, es decir, si se optara por desarrollar normativamente los preceptos que incurren en la inconstitucionalidad no declarada, se podrá impugnar dicha decisión legislativa mediante el correspondiente recurso de inconstitucionalidad o una eventual cuestión de inconstitucionalidad, o incluso plantear un conflicto de competencia cuando se invadieran competencias estatales. En todo caso, si se optara por la solución de la no aplicación hay que recordar que las leyes que no se aplican carecen de consecuencias, por lo que serían equivalentes a un reconocimiento de inconstitucionalidad por los poderes públicos autonómicos sin nulidad, adquiriendo una similar efectividad que el cumplimiento directo de la STC 31/2010.

$$
* * *
$$

TITLE: The effects of the STC 31/2010 of the statute of autonomy of Catalonia: the implications for his regulation of development and the bylaws of other autonomous communities

ABSTRACT: The effects of STC 31/2010 are approached mainly by means of the study of the general effects of the sentences of the Constitutional Court. Within the conclusions it has been of particular importance to take into account that the Statute of Autonomy is a head - norm of an own normative system, so that the nullity as well as the interpretation in conformity with the Constitution of its provisions implies a mandate susceptible of being examined as a specific binding effect of the sentences of the Constitutional Court. In this sense, it is capable to cause consequences for identical provisions of other legal norms that are in a relationship of dependence on and of hierarchical inferiority with those provisions of the Statute of Autonomy declared unconstitutional. Besides, the findings of the sentence may have even interpretive character for similar or identical provisions of the Statutes of other Autonomous Communities. Thus the consequences of the sentence are notably of interpretative character for other legal provisions; however, a direct enforcement would apply to the provisions of another legal norm declared unconstitutional due to the lack of conformity with the Constitution deriving from the main proceedings. norms.

KEYWORDS: Effects of the sentences of the Constitutional Court. Statute of Autonomy. Relationships between legal

Resumen: Los efectos de la STC 31/2010 se aborda fundamentalmente desde el estudio de los efectos generales de las sentencias del Tribunal Constitucional. En las conclusiones ha sido clave considerar que el Estatuto de Autonomía es norma de cabecera de un ordenamiento propio, de forma que la nulidad, así como la interpretación conforme a la Constitución de los preceptos estatutarios implica un mandato que es susceptible de ser examinado como efecto vinculatorio específico de la sentencia del Tribunal Constitucional. En este sentido, es susceptible de generar consecuencias en idénticos mandatos de otras normas legales que mantienen relaciones de dependencia e inferioridad jerárquica con los preceptos declarados inconstitucionales del Estatuto de Autonomía, o incluso de carácter interpretativo con los preceptos similares o idénticos de los Estatutos de otras Comunidades Autónomas. Estas consecuencias son fundamentalmente de carácter interpretativo, pero también es aplicable el incidente de ejecución forzosa cuando nos encontremos ante el mismo mandato declarado inconstitucional en otra norma por inconstitucionalidad derivada del proceso principal.

Palabras Clave: Efectos de las sentencias del Tribunal Constitucional. Estatuto de Autonomía. Relaciones entre normas.

FECHA DE RECEPCIÓN: 8.01.2011. Fecha de aceptación: 26.01.2011 